\title{
Genome-Wide Association Study Identifies NBS-LRR-Encoding Genes Related with Anthracnose and Common Bacterial Blight in the Common Bean
}

\section{OPEN ACCESS}

Edited by:

Raúl Alvarez-Venegas, Center for Research and Advanced Studies of the National Polytechnic Institute (CINVESTAV), Mexico

Reviewed by: Romesh Kumar Salgotra, Sher-e-Kashmir University of Agricultural Sciences and Technology of Jammu, India

Ana Margarida Fortes, Instituto de Biossistemas e Ciências

Integrativas (Bio/SI), Portugal

*Correspondence: Shumin Wang

wangshumin@caas.cn

${ }^{\dagger}$ These authors have contributed equally to this work.

Specialty section: This article was submitted to

Plant Biotechnology,

a section of the journal

Frontiers in Plant Science

Received: 11 May 2017

Accepted: 26 July 2017

Published: 09 August 2017

Citation:

Wu J, Zhu J, Wang L and Wang S (2017) Genome-Wide Association Study Identifies NBS-LRR-Encoding Genes Related with Anthracnose and Common Bacterial Blight in the Common Bean.

Front. Plant Sci. 8:1398. doi: 10.3389/fpls.2017.01398

\author{
Jing $W u^{\dagger}$, Jifeng $Z h u^{\dagger}$, Lanfen Wang and Shumin Wang * \\ Institute of Crop Sciences, Chinese Academy of Agricultural Sciences, Beijing, China
}

Nucleotide-binding site and leucine-rich repeat (NBS-LRR) genes represent the largest and most important disease resistance genes in plants. The genome sequence of the common bean (Phaseolus vulgaris L.) provides valuable data for determining the genomic organization of NBS-LRR genes. However, data on the NBS-LRR genes in the common bean are limited. In total, 178 NBS-LRR-type genes and 145 partial genes (with or without a NBS) located on 11 common bean chromosomes were identified from genome sequences database. Furthermore, 30 NBS-LRR genes were classified into Toll/interleukin-1 receptor (TIR)-NBS-LRR (TNL) types, and 148 NBS-LRR genes were classified into coiled-coil (CC)-NBS-LRR (CNL) types. Moreover, the phylogenetic tree supported the division of these PVNBS genes into two obvious groups, TNL types and CNL types. We also built expression profiles of NBS genes in response to anthracnose and common bacterial blight using qRT-PCR. Finally, we detected nine disease resistance loci for anthracnose (ANT) and seven for common bacterial blight (CBB) using the developed NBS-SSR markers. Among these loci, NSSR24, NSSR73, and NSSR265 may be located at new regions for ANT resistance, while NSSR65 and NSSR260 may be located at new regions for CBB resistance. Furthermore, we validated NSSR24, NSSR65, NSSR73, NSSR260, and NSSR265 using a new natural population. Our results provide useful information regarding the function of the NBS-LRR proteins and will accelerate the functional genomics and evolutionary studies of NBS-LRR genes in food legumes. NBS-SSR markers represent a wide-reaching resource for molecular breeding in the common bean and other food legumes. Collectively, our results should be of broad interest to bean scientists and breeders.

Keywords: common bean, NBS-LRR, disease resistance genes, anthracnose, common bacterial blight, association study

\section{INTRODUCTION}

The common bean is an important global pulse crop that can be used for human consumption or animal fodder. However, one of the main problems that limits bean production in every country is disease, such as anthracnose (Melotto et al., 2000; Singh and Schwartz, 2010), angular leaf spot (Schwartz et al., 1981; de Jesus et al., 2001; Bassanezi et al., 2002), powdery mildew (Trabanco et al., 2012), or common bacterial blight (Opio et al., 1996; Fourie, 2002; Zamani et al., 2011). Cultivating 
resistant varieties is the most economical and effective approach for controlling common bean diseases and is an important goal for common bean breeders. In recent years, the loss of diseaseresistant varieties has proven to be a challenge for common bean production. Therefore, the discovery of new disease resistance genes represents a vital task and an important precondition for breeding disease-resistant varieties of the common bean.

Nucleotide-binding site (NBS)-leucine-rich repeat (LRR) genes are the most important type of disease resistance genes in plants. The NBS domain participates in the transduction of the disease resistance signal in combination with ATP or GTP, and it contains Kinase 1, Kinase 2, and Kinase 3 and a conserved HD motif, which can be used to identify pathogenic effects on host cells (Meyers et al., 2003; Tameling et al., 2006). NBS-LRR are included two major classes: the first class contains a Toll/interleukin-1 receptor (TIR) motif at the C-terminus, and the second class contains the coiled-coil (CC) motif at the C-terminus (Meyers et al., 2003; McHale et al., 2006) In addition, the highly diverse LRR domain was identified at the N-terminal region (Bent, 1996; Martin et al., 2003). Many studies have shown that NBS-encoding proteins play a necessary role in plant disease resistance to diverse pathogens (Sekhwal et al., 2015). To date, more than 50 NBS genes have been cloned, and exhibited disease resistance functions (Sekhwal et al., 2015). Examples include the stripe rust resistance gene $\operatorname{Yr} 10$ (CC-NBS-LRR) in wheat (Liu et al., 2014), the stem rust resistance gene Sr33 (CC-NBS-LRR) in wheat (Periyannan et al., 2013), the powdery mildew resistance gene Mla1 (CC-NBS-LRR) in barley (Zhou et al., 2001), the flax rust resistance gene L6 (TIR-NBS-LRR) and $M$ (TIR-NBSLRR) genes in flax (Lawrence et al., 1995; Anderson et al., 1997), the fungal pathogen Peronospora parasitica resistance gene Rpp5 (TIR-NBS-LRR) in Arabidopsis (Noel et al., 1999), the tobacco mosaic virus resistance gene $N$ (TIR-NBS-LRR) in tobacco (Whitham et al., 1994), the bacterial blight-resistance genes Xa1 and xa5 (NBS-LRR) in rice (Yoshimura et al., 1998; Iyer and McCouch, 2004), the bacterial and downy mildew resistance gene RPS5 (NBS-LRR) in Arabidopsis (Warren et al., 1998), and the bacterial wilt resistance gene RRS1 (WRKY-TIR-NBS-LRR) in Arabidopsis (Deslandes et al., 2002). However, research on the NBS gene family in the common bean is weak. A previous report revealed that the Co-2 locus contains sequences encoding both NBS-LRR genes (Creusot et al., 1999), JA1tr has been reported to belong to the CC-NBS-LRR class of plant disease R genes (Ferrier-Cana et al., 2005), and the viral resistance gene RT44 is a member of the TIR-NBS-LRR family (Seo et al., 2006). In addition, the bean common mosaic virus resistance $I$ gene is located on Pv02 containing a cluster of NBS-LRR-type genes (Vallejos et al., 2006). Many TIR and non-TIR sequences in the common bean were obtained from conserved sequences in the NBS domains of Medicago truncatula (Garzon et al., 2013). In conclusion, information on NBS genes in the common bean is limited. Therefore, we should accelerate the identification of the NBS family, which will be beneficial to research into the resistance genes in the common bean.

Anthracnose (ANT) and common bacterial blight (CBB) are important diseases that limit bean production (Singh and Schwartz, 2010). More than 22 resistance genes for ANT (Ferreira et al., 2013; Campa et al., 2014; Gonzalez et al., 2015; Perseguini et al., 2016; Zuiderveen et al., 2016) and 26 resistance quantitative trait loci (QTLs) for CBB (Miklas et al., 2006; Liu et al., 2008; Shi et al., 2011; Xie et al., 2017) have been mapped on all common bean chromosomes. Moreover, genome-wide association studies (GWAS) are powerful and efficient tools for the discovery of novel genes of complex agronomic traits, such as disease resistance against stripe rust, leaf rust, and leaf spot in wheat (Gurung et al., 2014; Zegeye et al., 2014; Iquira et al., 2015; Gao et al., 2016) and the plant hypersensitive defense response genes in maize (Olukolu et al., 2014). Especially in the common bean, Perseguini et al. (2016) and Zuiderveen et al. (2016) identified SNPs or SSRs associated with ANT resistance on 10 common bean chromosomes using genome-wide association studies. Shi et al. (2011) selected SNPs for an association study to map CBB resistance QTL on 11 common bean chromosomes.

In the past 15 years, more than 60 monocot and dicot genomes have been sequenced and assembled (Phytozome v 11.0) in plants, such as in pulses, pigeon pea (Varshney et al., 2012), chickpea (Varshney et al., 2013), common bean (Schmutz et al., 2014; Vlasova et al., 2016), mung bean (Kang et al., 2014), and adzuki bean (Yang et al., 2015). Recently, NBS family sequences within the whole genomes of many plant species have been annotated. In total, 580 complete NBS genes in wheat (Bouktila et al., 2015), 332 NBS-LRR genes in rice (Zhang et al., 2015), 346 NBS-LRR genes in sorghum (Mace et al., 2014), 319 NBSLRR genes in soybean (Kang et al., 2012), 393 NBS-LRR genes in A. duranensis (Song et al., 2017), and 437 NBS-LRR genes in A. ipaënsis (Song et al., 2017) have been detected. However, few studies have investigated the NBS-LRR genes in the common bean at the whole genome level.

Based on annotated genome sequences of the common bean, Andean (G19833) and Mesoamerican (BAT93) genotypes of the common bean genome sequence were found to encompass a $472.5 \mathrm{Mb}$ sequence with 27,197 predicted proteins and a 549.6 $\mathrm{Mb}$ sequence with 30,491 protein-coding genes, respectively (Schmutz et al., 2014; Vlasova et al., 2016). These sequences provide an opportunity to explore the characteristics of the NBS genes in the common bean. Thus, the goals of this article are to: (1) identify NBS genes from the common bean; (2) characterize and analyse the genome organization and expression profiles of NBS genes in the common bean; (3) develop SSR markers for these NBS genes; and (4) detect ANT- and CBB-related loci using NBS-SRR markers by the association analysis method.

\section{MATERIALS AND METHODS}

\section{Plant Material, Pathogens, and Phenotypic Evaluation}

Two natural populations (183 cultivars and 100 cultivars) were used in the association study (Tables S1, S2). Four common bean genotypes, including Hongyundou (resistant to ANT), Jingdou (susceptible to ANT), HR45 (resistant to CBB), and Bilucaidou (susceptible to $\mathrm{CBB}$ ), were used to detect the expression profiles of the NBS genes. These seeds can be obtained from the National Gene Bank (China, Beijing). The seeds were planted in pots 
filled with moist vermiculite in a greenhouse in Beijing, China. For each plant, seedlings with five replicates were evaluated for ANT and CBB severity. Seedlings at the unifoliate growth stage were inoculated with a $1.2 \times 10^{6}$ spores $/ \mathrm{ml}$ suspension of Colletotrichum lindemuthianum strain 81 using a highpressure sprayer to evaluate $\mathrm{ANT}$ resistance at $20-22^{\circ} \mathrm{C}, 95-$ $100 \%$ controlled humidity in a control growth chamber (Balardin et al., 1990). Symptoms were scored at 7 days after inoculation. A 0-9 scale was used for disease severity ratings, with $0=$ no symptoms, $1=$ a few, very small lesions, $3=<10 \%, 5=$ $10-25 \%, 7=25-50 \%$, and $9=$ more than $50 \%$ of inoculated areas showing symptoms. The plants with fully expanded first trifoliate leaves were inoculated by the needle method (Zapata, 2006) to evaluate CBB severity. The fresh inoculum was prepared with Xanthomonas axonopodis pv. phaseoli isolate $\mathrm{XS}_{2}$ at a concentration of $10^{8} \mathrm{CFU} / \mathrm{ml}$. The inoculated plants were maintained in a greenhouse at $25-28^{\circ} \mathrm{C}$ and rated for $\mathrm{CBB}$ infection at 14 days after inoculation using a 1-10 scale (Zapata, 2006) to describe disease symptoms.

\section{Common Bean Genome Annotation Resources}

Overall, 27,197 protein-coding genes of the common bean were used (Schmutz et al., 2014) (https://phytozome.jgi.doe. gov/pz/portal.html\#! info?alias=Org_Pvulgaris). Transcript data were obtained from the Phytozome database (https:// phytozome.jgi.doe.gov/phytomine/template.do?name=One_ Gene_Expression\&scope=global).

\section{Identification of Sequences Encoding NBS Motifs in the Common Bean Genome}

Predicted proteins from the common bean genome were screened with HMMER V.3 (Finn et al., 2015) using the raw Hidden Markov Model (HMM) corresponding to the Pfam NBS (NB-ARC) family (PF00931). Then, the results were confirmed using the NCBI conserved domain database (http://www. ncbi.nlm.nih.gov/Structure/cdd/wrpsb.cgi) and Pfam database (http://pfam.sanger.ac.uk/). We used Pfam protein families (http://pfam.sanger.ac.uk/) to determine whether these genes encoded TIR (PF01582) or LRR (PF00560, PF07723, PF07725, PF12779, PF13306, PF13516, PF13855, PF14580, PF03382, PF01030, and PF05725) motifs. The COILS program was used to predict the CC motifs at a threshold of 0.9 (http://www. ch.embnet.org/software/COILS_form.html). All "NBS-LRR" tag proteins were downloaded from NCBI to identify partial NBSLRR genes. The proteins were BLAST searched against this database using an e-value $<10^{-40}$.

\section{Data Analyses}

Softberry was used to detect subcellular localization (http:// linux1.softberry.com/). The basic information of NBS genes was determined using ExPASy (http://www.expasy.ch/tools/pi_ tool.html). The NetNGlyc 1.0 server was used to predict the glycosylation sites of the NBS genes (http://www.cbs.dtu.dk/ services/NetNGlyc/). The exon/intron organization of the NBS gene was visualized with the Gene Structure Display Server (GSDS) program (Guo et al., 2007). The upstream promoter sequences of the NBS-LRR genes were identified using the PlantCARE database (Rombauts et al., 1999). Motifs of the NBS proteins were searched on MEME web (Bailey et al., 2009). A phylogenetic tree was constructed in ClustalX (Larkin et al., 2007) based on the amino acid sequences of NBS genes using default parameters, and the tree was generated by the neighbor-joining (NJ) method with bootstrap values using MEGA 4 (Tamura et al., 2007). The heat map was viewed by MeV software (http://www. tm4.org/mev.html).

\section{Development of SSR Markers}

SSR markers were developed using the software SSR Locator (da Maia et al., 2008). Various perfect di-, tri-, tetra-, and penta-nucleotide SSR motifs were searched. The numbers of replications of di-, tri-, tetra-, and penta-nucleotide SSR motifs were at least $10,7,5$, and 4 , respectively. The parameters for designing the primers were according to the description by Chen et al. (2014).

\section{Genotyping}

Genomic DNA was isolated from young leaves using a modified cetyltrimethyl ammonium bromide method (Afanador et al., 1993). In total, 283 NBS-SSR markers named with the prefix NSSR were mined based on 68 NBS-coding genes in the common bean. The PCR amplifications were performed in $15-\mu 1$ reactions containing $20 \mathrm{ng}$ of template DNA, $0.2 \mu \mathrm{mol} \mathrm{1^{-1 }}$ primers (Invitrogen, USA), $0.25 \mathrm{mmol}^{-1}$ dNTPs, $1.5 \mu \mathrm{l}$ of $10 \times$ Taq buffer with $1.5 \mathrm{mmol}^{-1} \mathrm{Mg}^{+}$, and $1 \mathrm{U}$ of Taq DNA polymerase in a $100^{\mathrm{TM}}$ Thermal Cycler (Bio-Rad Research, USA). The PCR thermocycling conditions were $5 \mathrm{~min}$ at $95^{\circ} \mathrm{C}$; followed by 35 cycles of $95^{\circ} \mathrm{C}$ for $45 \mathrm{~s}, 53^{\circ} \mathrm{C}$ for $45 \mathrm{~s}$ and $72^{\circ} \mathrm{C}$ for $45 \mathrm{~s}$; and a final extension of $10 \mathrm{~min}$ at $72^{\circ} \mathrm{C}$. The PCR products were separated on $8 \%$ non-denatured polyacrylamide gels.

\section{Statistical Analysis}

Association analysis between markers and phenotypes was performed with TASSEL 2.1 software under the general linear model (Bradbury et al., 2007). Markers were deemed to be associated with ANT or CBB disease if the markers were significant at $p<0.01$. Population structure was analyzed using the program Structure 2.2 (Pritchard et al., 2000). The parameter of subpopulations $(\mathrm{K})$ was set from 1 to 10 based on 10 independent runs of 100,000 interactions for the length of burnin period and 100,000 Markov Chain Monte Carlo replications.

\section{Quantitative Real-Time PCR (qRT-PCR) Analysis}

Leaf samples at $0,6,12$, and $24 \mathrm{~h}$ after inoculation were obtained from five seedlings and quickly frozen in liquid nitrogen for extracting RNA. Total RNA was extracted from leaf samples using RNAprep Pure Plant Kit (Tiangen, Beijng) following the manufacturer's instructions. The RNA samples was used to synthesize cDNA by reverse transcription using Transcriptor First Strand cDNA Synthesis Kit according to the manufacturer's manual (Roche, USA). The qRT-PCR reactions were performed on an ABI7500 Real-Time PCR (Bio-Rad Corporation, USA) using TransStart Top Green qPCR SuperMix (TransGen Biotech, 
China). Primers specific for all NBS genes were used for qRT-PCR (Table S3), with normalization to the internal control gene, Actin (Borges et al., 2012). Three replicates were performed, and the expression changes were calculated using the $2^{-\Delta \Delta C t}$ method for each sample (Livak and Schmittgen, 2001). In this study, a fivefold change in expression level was used as a cut-off point. Higher differentially expressed gene levels in susceptible variety samples than in resistant variety samples were denoted by "up-regulated" vs. "down-regulated."

\section{RESULTS}

\section{NBS Genes in Common Bean}

Overall, 325 gene candidates in which the HMM corresponded to the Pfam NBS family were identified (Table S4). Finally, 227 non-redundant NBS genes were identified, of which 178 fulllength protein sequences were used for the subsequent analyses (Table S5) and named PvNBS1-PvNBS178. Furthermore, we obtained 95 R genes without the NBS domain (Table 1, Table S6). We classified 178 full-length proteins into the TNL or CNL families based on the protein sequences of each NBS-LRR candidate. The CNL group included 148 full-length NBS-LRR candidates, NCC (40, without CC and LRR), CN (17, without the LRR), CNL (33), and NLCC (58, without CC). The remaining 30 genes belonged to the TNL group: NTIR TN (4 in the NBS domain from the TIR type and 4 in the TIR and NBS domains but not in the LRR domain), TNL (18 in the TIR, NBS, and LRR domains), and NLTIR (4, without TIR domain) (Table 1, Table S5).

The common bean NBS-LRR genes are distributed across all 11 chromosomes (Chr1-Chr11); however, Phvul.L001800, Phvul.L003300, and Phvul.L006800 remained on unmapped scaffolds (Figure 1, Table S7). The PvNBS genes distribution on common bean chromosomes have no any rules. Total of 96 PvNBS genes were located on three chromosomes: 23 PvNBS genes on Chr4, 18 PvNBS genes on Chr10, and 55 PvNBS genes on Chr11. CNLs were present on Chr1-Chr11, whereas TNLs were absent from Chr8 and Chr9. The greatest number of NB-LRRs was identified on Chr11, which harbored 55 genes;

TABLE 1 | Classification of the NBS-LRR genes in the common bean genome.

\begin{tabular}{llc}
\hline NBS Type & Letter code & Common bean \\
\hline CNL type & & 148 \\
NBS & $N_{\text {CC }}$ & 40 \\
CC-NBS & CN & 17 \\
CC-NBS-LRR & CNL & 33 \\
NBS-LRR & $N_{\text {CC }}$ & 58 \\
TNL type & & 30 \\
NBS & $N_{\text {TIR }}$ & 4 \\
TIR-NBS & TN & 4 \\
TIR-NBS-LRR & TNL & 18 \\
NBS-LRR & NLTIR & 4 \\
Partial (with NBS) & $P_{\text {NBS }}$ & 50 \\
Partial (without NBS) & $P$ & 95 \\
\end{tabular}

however, only one NBS-LRR gene was distributed on Chr9. Moreover, $39 \%$ of all the TNL genes were distributed on Chr10, whereas $28 \%$ of all the CNL genes were distributed on Chr11. The distribution of NBS-LRR genes tended to form clusters among the chromosomes. To form a cluster, there must be $>$ $200 \mathrm{~kb}$ distance between neighboring NBS-LRRs and fewer than eight non-NBS-LRR genes between the NBS-LRRs (Lozano et al., 2015). Based on this standard, we identified 129 NBS-LRR genes belonging to 22 clusters, and the average number of NBS-LRR genes in a cluster was 5.86 (Figure 2, Table S7). Chromosomes 10 and 11 had the highest number of clusters at 4 . The number of members per cluster ranged from 2 to 34 . Cluster 21 had the highest number of members at 34 genes. In addition, 49 NBSLRR singletons were distributed on all the chromosomes. The cluster size ranged from 9,264 to $1,805,165 \mathrm{bp}$.

\section{Gene Structural Characteristics, Phylogenetic Relationships, and Analysis of the Conserved Motifs of the NBS Genes}

We analyzed the genomic sequences, CDS, protein lengths, NW, pI, glycosylation sites, and subcellular localization of the 178 full-length NBS genes (Table S5). The length of the genomic sequences of these NBS genes ranged from 1,157 to 15,770 bp, the CDS length ranged from 978 to $9,480 \mathrm{bp}$. The protein length ranged from 325 AA (Phvul.010G054400) to 3,159 AA (Phvul.010G091100), and the MW ranged from $37.20 \mathrm{kDa}$ to $360.50 \mathrm{kDa}$, and the $\mathrm{pI}$ ranged from 5.04 to 9.17. We also predicted the number of glycosylation sites, which ranged from 0 to 37. Phvul.010G091100 contains 37 sites, whereas Phvul.003G247500 does not contain any sites. The results of subcellular localization prediction showed that 170 proteins were located in the extracellular region, 6 NBS proteins were located in the cytoplasm, Phvul.008G061300 was located in the plasma membrane, and Phvul.010G054400 was located in the endoplasmic reticulum. The average number of exons of these NBS genes was 3.10. We also found that the average number of exons in the TNL genes was higher (5.56) than the number of exons in the CNL genes (2.74). Furthermore, $39.4 \%$ of the CNL genes had a single exon.

All common bean NBS protein sequences were used to conduct a phylogenetic tree. Overall, 178 NBS genes can be separated to two different groups. The first clade included all CNL-type proteins and could be classified into nine major groups: I, II, III, IV, V, VI, VII, VIII, and VX (Figure S1). Group I was the largest group (49 members) and accounted for $33.1 \%$ of all CNL-type proteins, and most of the members were located on Chr11. In contrast, Group III contained only one member, Phvul.005G031200. We also noticed that most of members of groups II and V were located on Chr4 and Chr2, respectively. The second clade contained all TNL proteins and showed clear separation with the CNL.

We detected conserved motifs with the amino acid sequences of complete CNL (33) and TNL (18) proteins using MEME (Figures 3, 4). The results showed that the P-loop, kinase-2, NBS-A to -D, GLPL, and MHDV motifs were also detected in the CNL members, whereas the NBS-A and $-\mathrm{C}$ motifs were 


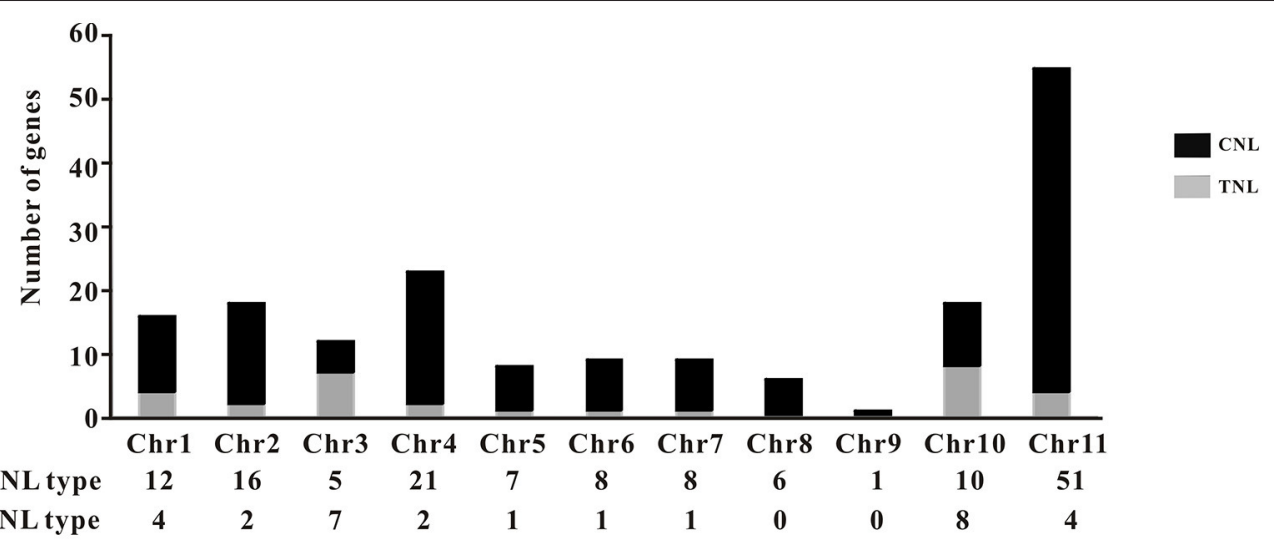

FIGURE 1 | Distribution of the TNL- and CNL-type genes. The distribution of the genes in each type is shown on the common bean chromosomes. The bars are divided into CNL types (black) and TNL types (gray).

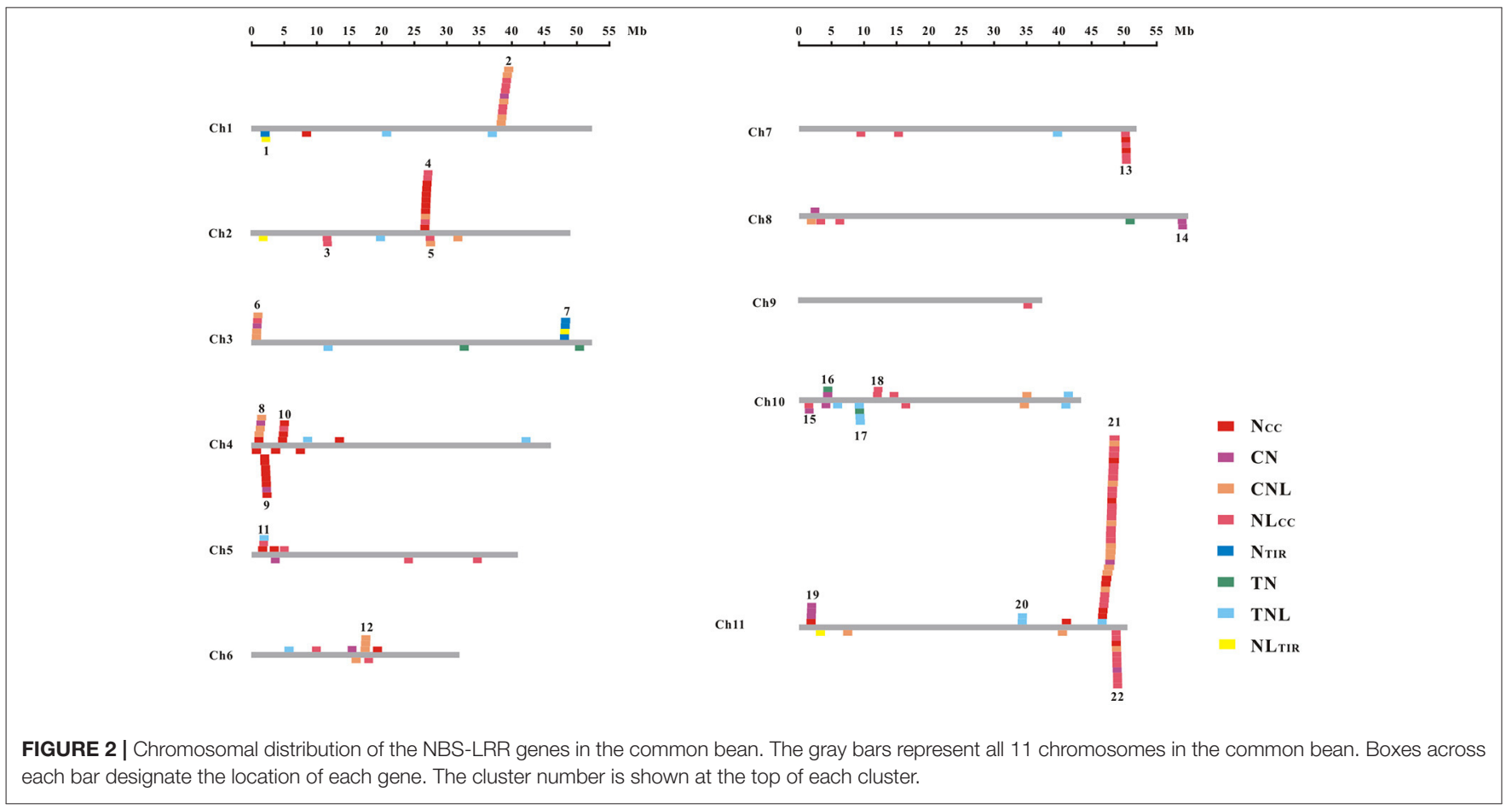

absent in the TNL group. Then, the P-loop, kinase-2, GLPL, and MHDV displayed a high level of similarity between the CNL and TNL proteins, and the RNBS-D motif presented low similarity between the common bean CNL and TNL proteins. Furthermore, the MHDV motif in the CNL and TNL proteins in the common bean was modified into a MHDL motif. However, motifs TIR-1, TIR-2, TIR-3, and TIR-4 were detected in the Nterminus of the TNL protein, and the order of these motifs was consistent with other species. Among the TNL proteins, TIR-2 and TIR-4 were deleted in the Phvul.010G055100 protein, whereas other TNL proteins contained all four motifs. In addition, the CC- 1 and CC- 2 motifs were detected at the $\mathrm{N}$-terminus of the CNL protein. Half of the CNL proteins contained these two motifs. Finally, we detected two motifs and one motif in the LRR region of the TNL and CNL proteins, respectively.

\section{Cis-Element Analysis}

Approximately 1,500 bp sequences upstream of the start codon were isolated and used to identify putative CAREs using the PlantCARE database. Ninety similar CAREs associated with abiotic stress, hormones, tissue-specific expression, light responsiveness, and other elements were identified (Table S8). A large number of light-responsive elements were detected in the promoter regions of the PvNBS genes, such as Box 4, Box I, G-box, and the GAG-motif. Furthermore, CAREs 


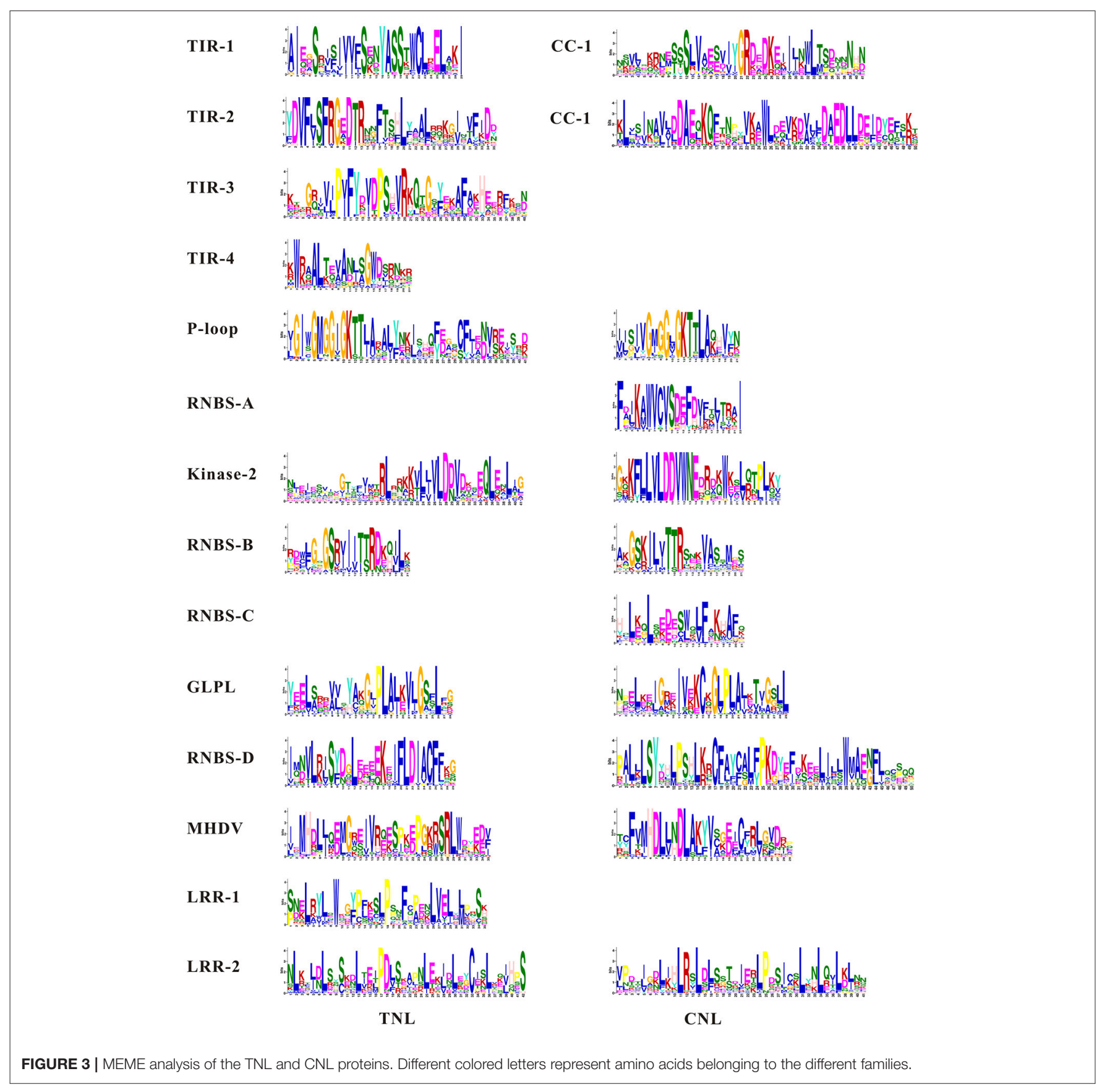

involved in plant hormones were also identified, for example, abscisic acid responsiveness element (ABRE, CE1 and CE3), the gibberellin-responsive element (TATC-box and P box), and salicylic acid responsiveness element (CGTCA-motif and SARE). Finally, elements that are important in abiotic stress were identified in most of the PvNBS genes, such as the WUNmotif and Box-W1, were detected. Moreover, TC-rich repeats involved in defense and stress responsiveness. In addition, G-box, GT1, and Box-W1, which are involved in defense gene expression induced by pathogen or fungal elicitors, were also detected in most of the NBS-LRR genes (Rushton et al.,
1996; Faktor et al., 1997; Yamamoto et al., 2004; Shi et al., 2013).

\section{Expression Profiles of the NBS Genes in Response to Anthracnose and Common Bacterial Blight}

Expression data were not available for Phvul.007G254400, Phvul.004G053000, or Phvul.010G025700 in the publicly RNAseq data. The expression profiles of 175 NBS-LRR genes were obtained in 9 common bean tissues (Figure S2, Table S9). Most of the PvNBS genes were expressed in 9 tissues (120 genes, 
A

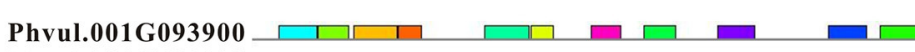

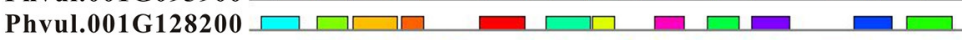

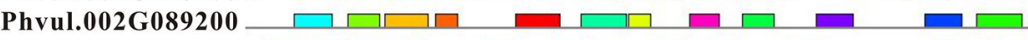

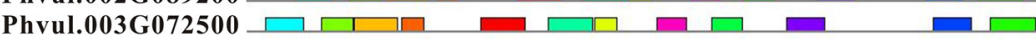

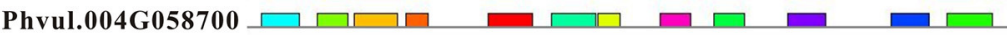

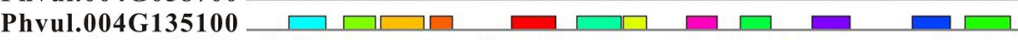

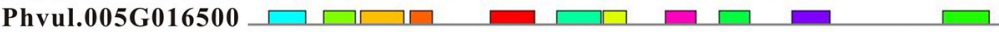

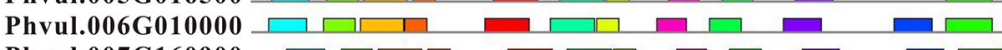

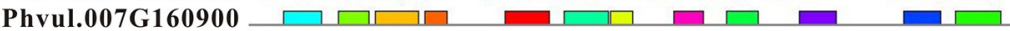

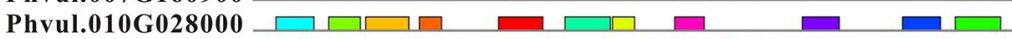

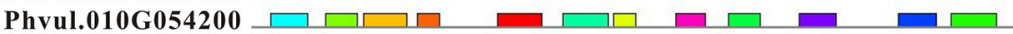

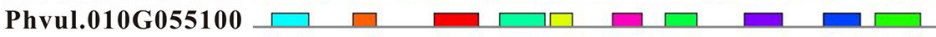

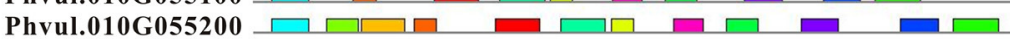

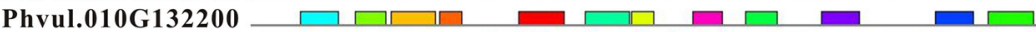

Phvul.010G136800 एमा एव

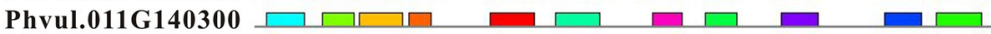

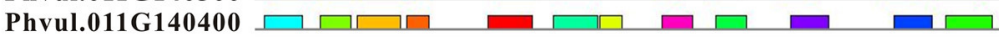

Phvul.011G181400 $\square+\square \square$

$\square_{\text {TIR-1 }} \square_{\text {TIR-2 }} \square_{\text {TIR-3 }} \square_{\text {TIR-4 }} \square_{\text {P-loop }} \square_{\text {Kinase-2 }} \square_{\text {RNBS-B }} \square_{\text {GLPL }} \square_{\text {RNBS-D }} \square_{\text {MHDV }} \square_{\text {LRR-1 }}$

B

\begin{tabular}{|l|} 
Phvul.001G132300 \\
Phvul.001G132700 \\
Phvul.001G133400 \\
Phvul.001G134400 \\
Phvul.001G134500 \\
Phvul.002G129900 \\
Phvul.002G135600 \\
Phvul.002G166400 \\
Phvul.003G002500 \\
Phvul.003G000260 \\
Phvul.003G003000 \\
Phvul.004G008000 \\
Phvul.004G008400 \\
Phvul.004G009300 \\
Phvul.006G041400 \\
Phvul.006G051500 \\
Phvul.006G052300 \\
Phvul.006G052400 \\
Phvul.008G014700 \\
Phvul.010G091100 \\
Phvul.010G091900 \\
Phvul.011G074800 \\
\hline Phvul.011G151300 \\
Phvul.011G192100 \\
Phvul.011G192600 \\
Phvul.011G192900 \\
Phvul.011G193500 \\
Phvul.011G193600 \\
Phvul.011G193800 \\
Phvul.011G195000 \\
Phvul.011G196000 \\
Phvul.011G198300 \\
Phvul.011G201000
\end{tabular}

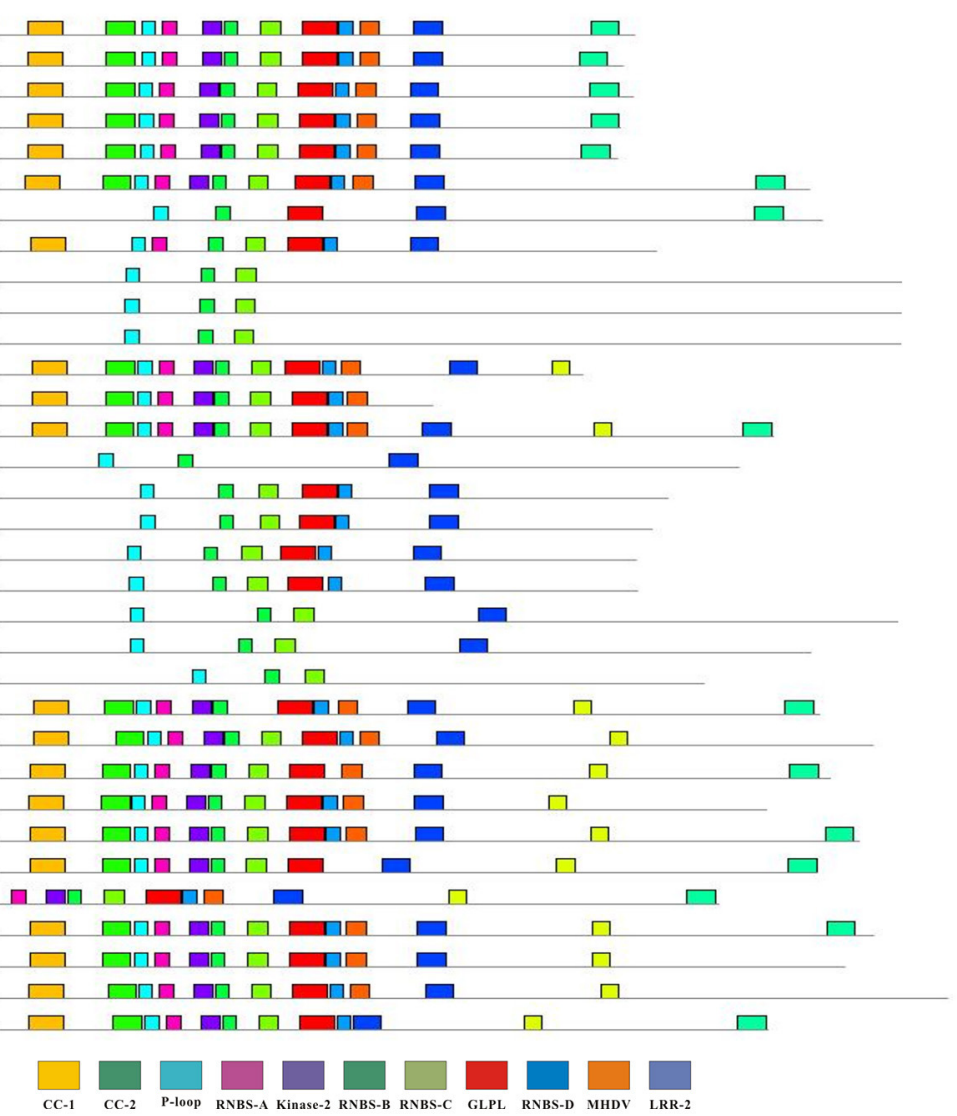

FIGURE 4 | Composition of the conserved motifs in NBS genes in the common bean. The conserved motifs of the common bean NBS-LRR genes were elucidated using MEME. The conserved motifs are represented by different colored boxes. (A) The conserved motifs in TIR-NBS-LRR. (B) The conserved motifs in CC-NBS-LRR.

68.6\%), and no tissue expressed all the PvNBS genes. PvNBS genes were most abundant in the stems (161 genes, 92.0\%), followed by the roots (160 genes, 91.4\%). Few PvNBS genes were expressed in the flower buds (142 genes, 81.1\%). All the PvNBS genes were divided into 10 groups based on their expression patterns. Phvul.001G018800, Phvul.003G247200, Phvul.008G014700, and Phvul.011G014300 were showed highly expressed in most of common bean organs throughout the growing stage, whereas Phvul.001G132700, Phvul.001G132800, Phvul.002G129500, Phvul.002G130300, Phvul.005G020300, 
Phvul.010G023200, Phvul.011G154000, Phvul.011G181600, and Phvul.011G194900 were expressed at low levels in the common bean. In addition, Phvul.007G254200, Phvul.010G055100, Phvul.010G025100, and Phvul.011G193800 were specifically expressed in the roots, young pods, flowers, and flower buds, respectively.

Next, the expression profiles of all PvNBS genes in response to ANT and CBB infection in resistant and susceptible lines were studied by qRT-PCR. Among 178 NBS genes, 7 genes (Phvul.002G135100, Phvul.004G005600, Phvul.004G008000, Phvul.004G015800, Phvul.005G020300, Phvul.011G192600, and Phvul.011G196100) were not analyzed by qRT-PCR as no suitable primers were screened.

Of the remaining 171 NBS genes, 67 genes showed differential expression levels (fold change $\geq 5$ or $\leq 0.2$ ) between resistant and susceptible genotypes for ANT and CBB (Table S10). For ANT, the number of up-regulated genes (48) was higher than the down-regulated genes (19) in the susceptible cultivar (Jingdou) compared to the resistant cultivar (Hongyundou). By contrast, more down-regulated genes (43) than up-regulated genes (24) were identified in the susceptible line (Bilucaidou) compared to the resistant line (HR45) for CBB. In addition, 29 genes showed differential expression in resistant and susceptible cultivars for both diseases. Meanwhile, 11 genes showed the same expression pattern in resistant and susceptible genotypes for two diseases: 4 genes were up-regulated, and 7 genes were down-regulated. Eighteen genes shared opposite tendency of expression changes between ANT and CBB: 14 genes were up-regulated for ANT but down-regulated for $\mathrm{CBB}$, and 4 genes were down-regulated for ANT but up-regulated for CBB (Figure S3, Table S10).

According to ANT, 113 NBS genes showed differential expression (fold change $\geq 5$ or $\leq 0.2$ ) in at least at one time point compared to $0 \mathrm{~h}$ (Table S10). A range of expression patterns of these genes was observed in specific genotypes at different time points: 40 genes showed significant responses only in the resistant genotype (Hongyundou) and 37 genes only in the susceptible genotype (Jingdou) following fungal infection, whereas 36 genes were expressed in both genotypes after inoculation. Among the 36 genes, 31 showed differential expression patterns in the resistant and susceptible genotypes for ANT from 0 to $48 \mathrm{~h}$ after inoculation: 12 genes showed up-regulation only in the resistant genotype at 6,12 , or $24 \mathrm{~h}$ but down-regulation or no change in the susceptible genotype at any time point. In contrast, 5 genes showed up-regulation only in the susceptible genotype but down-regulation or no regulation in the resistant genotype at $6 \mathrm{~h}$.

For CBB, the expression of 141 genes was significantly altered (fold change $\geq 5$ or $\leq 0.2$ ) in at least at one time point compared to $0 \mathrm{~h}$ (Table S10). Among these genes, 40 genes were changed only in the resistant genotype (HR45), 49 genes only in the susceptible (Bilucaidou), and 52 genes in both genotypes induced by $\mathrm{XS}_{2}$. Of the common 52 genes, 10 genes showed the same expression pattern in two genotypes from 0 to $48 \mathrm{~h}$ after inoculation, 11 genes showed down-regulation only in the resistant genotype but up-regulation or no regulation in the sensible cultivar after pathogen infection, and 8 genes showed higher expression levels in the resistant genotype than in the susceptible genotype after inoculation. Twelve genes in the resistant genotype were increased to the highest expression levels at $12 \mathrm{~h}$ only and then decreased at $24 \mathrm{~h}$, while these genes remained stable at 6 and $12 \mathrm{~h}$ or reached lowest expression levels at $12 \mathrm{~h}$ then increased at $24 \mathrm{~h}$ in the susceptible genotype.

\section{Development of SRR Markers Around the NBS Genes}

We developed SSR markers around the NBS-LRR genes to improve the accuracy of NBS gene mapping. For the singletons, $500-\mathrm{kb}$ sequences upstream and downstream of the gene were isolated and used to detect the SSR locus (Table S11). For the clusters, the sequences between the first and last genes were isolated and used to detect the SSR locus (Table S12). First, we searched for SSR motifs in the DNA sequences. Overall, 245 and 1,149 perfect microsatellites were detected in the DNA sequences of the NBS-LRR genes and singletons, respectively. In total, 571 SSR markers were developed for the NBS genes (Tables S11, S12). The microsatellites of these SSR markers included 369 (64.6\%) dinucleotide motifs, 107 (18.7\%) tri-nucleotide motifs, 41 (7.2\%) tetra-nucleotide motifs, and 54 (9.5\%) penta-nucleotide motifs. The AT/TA types were more abundant (86.7\%) than the AG/TC (8.7\%) and AC/TG types (0.8\%). However, we don't identified CG/GC types in the DNA sequences of the NBS-LRR regions.

\section{Association Studies of ANL and CBB Resistance Genes using NBS-SRR Markers in the Common Bean}

To identify genes related to ANL and CBB resistance in the common bean, we chose 68 markers for association studies, with one marker for each NBS singleton/cluster. The results of the structure simulation showed that a maximum log likelihood was attained at $K=2$, suggesting that two subpopulations could contain all accessions with the greatest probability (Figure $\mathbf{S 4}$ ). Finally, nine markers were associated with ANT and seven markers with $\mathrm{CBB}$ disease as indicated by the probability values $(p<0.01)$ (Table 2). The phenotypic variance explained $\left(R^{2}\right)$ ranged from 8.9 to $18.0 \%$ for ANT and 6.0 to $24.4 \%$ for CBB. Statistically significant associations involving NBS-SSR markers were observed for ANT on seven chromosomes and for CBB on five chromosomes. On chromosomes for ANT, two SSR markers located on Chr11, NSSR271 and NSSR281, and the marker NSSR24 (Chr2) showed significant $(p<0.001)$ associations with ANT resistance. The marker NSSR271 was the most significantly associated with ANT, explaining $18.0 \%$ of the phenotypic variation. On chromosomes for CBB, four SSR markers, NSSR32 and NSSR34, both located on Chr3, and NSSR240 (Chr4) and NSSR245 (Chr7) showed significant $(p<0.001)$ associations. NSSR240 showed the most significant association with CBB, explaining $24.4 \%$ of the phenotypic variation. The SSR marker NSSR65, located on Chr4, was associated with both diseases, suggesting a possible pleiotropic effect.

Furthermore, we compared these loci with known ANT and CBB loci. Among these association markers, NSSR8, NSSR65, NSSR117, NSSR234, NSSR271, and NSSR281 may be located at the same regions identified for ANT resistance in previous studies (Ferreira et al., 2013; Campa et al., 2014; Gonzalez 
TABLE 2 | SSR markers associated with ANT and CBB severity in 183 common bean germplasms $(p<0.01)$.

\begin{tabular}{|c|c|c|c|c|c|c|c|c|c|}
\hline \multirow[t]{2}{*}{ Marker } & \multirow[t]{2}{*}{ Gene } & \multirow[t]{2}{*}{ Marker position (bp) ${ }^{a}$} & \multirow[t]{2}{*}{ Chromosome } & \multicolumn{3}{|c|}{ ANT } & \multicolumn{3}{|c|}{ CBB } \\
\hline & & & & $F$ ratio & $p$-value & $R^{2}(\%)^{\mathrm{b}}$ & $F$ ratio & $p$ value & $R^{2}(\%)^{\mathrm{b}}$ \\
\hline NSSR8 & Phvul.001G128200.1 & $36182090-36174911$ & 1 & 2.89 & $4.8 \times 10^{-3}$ & 11.7 & & & \\
\hline NSSR24 & Phvul.002G166400.1 & 30830902-30828082 & 2 & 8.91 & $2.0 \times 10^{-4}$ & 8.9 & & & \\
\hline NSSR32 & Phvul.003G072500.1 & $10994765-11000821$ & 3 & & & & 4.91 & $3.3 \times 10^{-4}$ & 13.2 \\
\hline NSSR34 & Phvul.003G129700.1 & $31823313-31828331$ & 3 & & & & 4.02 & $8.6 \times 10^{-4}$ & 12.4 \\
\hline NSSR65 & Phvul.004G135100.1 & $41368421-41363361$ & 4 & 3.51 & $1.5 \times 10^{-3}$ & 12.0 & 3.01 & $5.3 \times 10^{-3}$ & 11.0 \\
\hline NSSR73 & Phvul.005G020300.1 & $1746532-1749452$ & 5 & 6.61 & $1.7 \times 10^{-3}$ & 6.6 & & & \\
\hline NSSR117 & Phvul.006G066800.1 & $18546221-18542599$ & 6 & 4.37 & $2.2 \times 10^{-3}$ & 9.4 & & & \\
\hline NSSR197 & Phvul.011G030000.1 & 2539794-2544217 & 11 & & & & 5.66 & $4.2 \times 10^{-3}$ & 6.0 \\
\hline NSSR234 & Cluster 8 & 673367-877733 & 4 & 3.65 & $3.6 \times 10^{-3}$ & 9.0 & & & \\
\hline NSSR240 & Cluster 10 & 4020210-4069578 & 4 & & & & 2.66 & $4.9 \times 10^{-4}$ & 24.4 \\
\hline NSSR245 & Cluster 13 & $49260558-49310456$ & 7 & & & & 5.54 & $9.3 \times 10^{-5}$ & 13.7 \\
\hline NSSR260 & Cluster 16 & $3728084-3754731$ & 10 & & & & 4.02 & $8.5 \times 10^{-3}$ & 6.4 \\
\hline NSSR265 & Cluster 17 & $8568461-8788327$ & 10 & 3.52 & $1.5 \times 10^{-3}$ & 12.2 & & & \\
\hline NSSR271 & Cluster 19 & $1111792-1156724$ & 11 & 4.73 & $3.0 \times 10^{-5}$ & 18.0 & & & \\
\hline NSSR281 & Cluster 21 & $45753810-47558975$ & 11 & 4.93 & $8.7 \times 10^{-4}$ & 9.7 & & & \\
\hline
\end{tabular}

a Physical location of genes in the G19833 genome.

${ }^{b} R^{2}$ indicates the percent of phenotypic variation explained by each marker.

et al., 2015; Perseguini et al., 2016; Zuiderveen et al., 2016). Among the CBB resistance loci, NSSR32, NSSR34, NSSR240, and NSSR245 may be located in the same CBB resistance QTL region based on map positions reported in previous studies (Miklas et al., 2006; Liu et al., 2008; McConnell et al., 2010; Shi et al., 2011). The NSSR65 marker was associated with both diseases but was located far away from the other marker linked with the CBB resistance QTL. In addition, one important locus (SAP6-QTL) for CBB resistance in the common bean has been reported at approximately $39.9 \mathrm{Mb}$ on Chr10 (Miklas et al., 2003; Shi et al., 2011). NSSR260, which was associated with CBB resistance, was identified at $3.7 \mathrm{Mb}$ on Chr10. Previous studies have associated different regions of Chr10 with $\mathrm{CBB}$ resistance. No major ANT resistance genes have been reported on Chr10, except a SNP at $3.8 \mathrm{Mb}$ associated with a minor QTL (Zuiderveen et al., 2016). The NBS-SSR marker NSSR265 at 8.6 $\mathrm{Mb}$ on Chr10 identified in our study was associated with ANT resistance, potentially revealing a new region for ANT resistance. Furthermore, NSSR24 (Chr2) and NSSR73 (Chr5) are located far from other markers linked with ANT resistance genes in previous studies based on physical position (Perseguini et al., 2016; Zuiderveen et al., 2016), suggesting new locations for ANT resistance.

For these new locations, NSSR24, NSSR65, NSSR73, NSSR260, and NSSR265, we selected another nature population for association studies of ANT and CBB resistance (Table S13). The results showed that only NSSR65 for CBB was not detected in the population by the probability values $(p<0.01)$. In the population, NSSR260 explained $14.9 \%$ of the phenotypic variation for CBB. NSSR24, NSSR73, and NSSR265 explained 9.8, 8.8, and 15.9\% of the phenotypic variance for ANT, respectively. The result confirmed the utility of these markers associated with these new loci linked to ANT/CBB.
Furthermore, we analyzed the expression patterns of the five locations, including nine NBS genes in resistant and susceptible cultivars for ANT/CBB. Among these NBS genes, two belonged to cluster 16 co-localized with a locus for CBB resistance, and four belonged to cluster 17 co-localized with a locus for ANT resistance (Table 2, Table S7). Of these NBS genes, Phvul.010G054400 and Phvul.010G055200 showed downregulation only in the resistance line (Hongyundou) at all times points after inoculation with the ANT pathogen, race 81. In terms of the levels of expression, Phvul.010G054400 and Phvul.010G055100 were expressed approximately 21- and 43-fold higher in Hongyundou than in Jingdou, respectively. For CBB, Phvul.010G025200 expression in the resistant cultivar (HR45) was significantly lower than in the susceptible cultivar (Bilucaidou) before inoculation. The expression level of the gene increased significantly at $0-12 \mathrm{~h}$ and was slightly reduced at $24 \mathrm{~h}$ in the resistant genotype after infection. In the susceptible genotype, expression increased at $0-6 \mathrm{~h}$ then dropped significantly to almost no noticeable expression at $12 \mathrm{~h}$, followed by significantly increased expression at $24 \mathrm{~h}$ but was still significantly lower than that in HR45.

\section{DISCUSSION}

The common bean is the world's most important food legume and belongs to the Fabaceae family, which includes many economically species, for example, mung bean, fava bean, and cowpea (Gepts et al., 2005; Cannon et al., 2009; Blair et al., 2016). The common bean is important as a source of grain for human consumption, and it is also used to produce protein concentrates for animal feed (Jansman, 2005). Because of the importance of the common bean, the development of disease-resistant cultivars 
is essential. Thus, the common bean genome sequences provides us an opportunity to identify, classify, and develop NBS-SSR markers for molecular breeding of disease-resistant cultivars.

Up to now, many important NBS-LRR genes involving to disease resistance have been cloned (Bryan et al., 2000; Zhou et al., 2001; Periyannan et al., 2013; Saintenac et al., 2013). In this article, 228 NBS domain genes and 95 partial NBS-LRR genes were detected, which represented $1.19 \%$ of all the common bean's predicted proteins. This number is higher than that of cassava $(\sim 0.9 \%)$, Arabidopsis $(\sim 0.43 \%)$, and $V$. vinifera $(\sim 0.91 \%)$ (Meyers et al., 2003; Yang et al., 2008; Lozano et al., 2015). NBS genes can be classified into the TNL or CNL families. The TIR and $\mathrm{CC}$ sequences have obvious differences between dicots and monocots (Cheng et al., 2012). The TIR motif is rarely present in disease resistance genes in monocots, such as $O$. sativa, $T$. aestivum, Z. mays, S. bicolor, B. distachyon, and other plants (Zhou et al., 2004; O’Toole et al., 2008; Cheng et al., 2012; Tan and $\mathrm{Wu}, 2012$; Jain et al., 2013; Ling et al., 2013; Bouktila et al., 2014; Mace et al., 2014; Wang et al., 2014; Gu et al., 2015; Singh et al., 2015). In contrast, most dicots contain TNL, including A. thaliana (51), P. trichocarpa (119), M. truncatula (152), M. $x$ domestica (218), and G. raimondii (35) (Meyers et al., 2003; Lurin et al., 2004; Shiu et al., 2004; Arya et al., 2014; Song and Nan, 2014; Yu et al., 2014). Among these NBS-LRR genes, we identified 18 TIR-NBS-LRRs and 33 CC-NBS-LRRs. The number of CNL genes was greater than the number of TNL genes, which is generally consistent with the results observed in other dicots, such as $V$. vinifera (203 CNL and $97 \mathrm{TNL}$ ), M. esculenta (117 CNL and 29 TNL), and S. lycopersicum (118 CNL and 18 TNL) (Yang et al., 2008; Lozano et al., 2012; Andolfo et al., 2014).

NBS-LRR genes contain three domains: an N-terminal TIR/CC domain, a central NBS domain, and a C-terminal LRR domain (Meyers et al., 2003; Song and Nan, 2014). TIR-1, -2, -3 , and -4 were detected in the N-terminus of TNL genes from the common bean, which is consistent with results observed in Arabidopsis thaliana and Populus trichocarpa (Meyers et al., 2003; Kohler et al., 2008). In contrast, only two motifs were identified in the N-terminus of CNL genes from the common bean, which is inconsistent with the results observed in other species, such as A. thaliana or P. trichocarpa (Meyers et al., 2003; Kohler et al., 2008). For the C-terminal LRR domain, two and one motifs were detected in the TNL and CNL families, respectively. The NBSencoding genes are divided into eight conserved motifs (Meyers et al., 2003). RNBS-A and RNBS-C were deleted in the TNL family from the common bean; however, the NBS-A motif was also deleted in the TNL members from Brassica rapa (Mun et al., 2009). The sequences of the motifs also differed in other species. Furthermore, the MHDV motif in TNL and CNL proteins was often changed to a MHDL motif, which is different from that of B. rapa (MHSL), P. trichocarpa (MHDL, QHDV and QHDL), and maize (MHDL) (Kohler et al., 2008; Mun et al., 2009; Cheng et al., 2012).

As previously reported, the complexity of the clusters of NBS genes caused rapid gene evolution (Friedman and Baker, 2007). These clusters have been identified in many plants. Seventy percent of the cassava NBS-LRR genes are located within a cluster (Lozano et al., 2015). The NBS genes of Solanum tuberosum were identified in high-density clusters (Lozano et al., 2012). In soybean, 40 NBS-LRR genes were clustered on Chr16, and 32 NBS-LRR genes were clustered on Chr18 (Kang et al., 2012). In Brachypodium distachyon, 43 genes were located in 11 clusters (Tan and $\mathrm{Wu}, 2012)$. In M. truncatula, 309 NBS genes were located in 78 gene clusters (Song and Nan, 2014). In the common bean, 26 CNL-encoding genes were found in the approximately $650-\mathrm{kb}$ region (David et al., 2009). In this study, the average number of NBS proteins in a cluster was 5.86, and it was greater than the ratios in A. thaliana (3.21), maize (2.77), B. distachyon (4) and M. truncatula (3.96) (Meyers et al., 2003; Cheng et al., 2012; Tan and Wu, 2012; Song and Nan, 2014).

In this paper, we analyzed the expression patterns of these NBS genes at different organs and different times after ANT/CBB pathogen infection. Expression pattern studies are the foundation of expounding gene function. RNA-seq data showed that some NBS genes were expressed in all organs examined. These results are similar to NBS genes from other crops, such as Pi64 in rice (Ma et al., 2015), Sr35 in wheat (Saintenac et al., 2013), and ZmNBS28 in maize (Cheng et al., 2012). In contrast, some NBS genes were specifically expressed at only one organ or stage, i.e., Phvul.007G254200 was expressed in the root, Phvul.010G055100 in the young pod, and Phvul.010G025100 in the flower. Similar reports are available in other crop studies. For example, $\mathrm{Pb} 1$ showed resistance only during adult stages in rice (Hayashi et al., 2010), Glyma12g03040 was expressed at 3-week-old nodules in soybean (Hayashi et al., 2012), and ZmNBS1 was expressed at the root in maize (Cheng et al., 2012). Some NBS genes showed significant expression differences between resistant and susceptible lines, such as Phvul.004G008400 and Phvul.011G192400 for ANT disease and Phvul.002G129900 and Phvul.011G200900 for CBB disease. Differences between genotypes were also observed in other crops, such as Sr35 in wheat (Saintenac et al., 2013), Bol016084 in cabbage (Kim et al., 2015), and Phvul.001G243700 in the common bean (Chen et al., 2017). In addition, some genes were found to be highly induced in resistant lines after pathogen infection. For instance, Phvul.004G012900, Phvul.004G013100, Phvul.001G134500, and Phvul.002G129900 expression was increased only in the resistant line after inoculation with pathogens. The Arabidopsis gene AT3G14460 was homologous to Phvul.001G134500, which was up-regulated 7.3-fold in Arabidopsis thaliana post-Bacillus subtilis FB17 colonization (Lakshmanan et al., 2013). In contrast, some gene expression changed extremely in susceptible cultivars infected with pathogen, including Phvul.001G132800 and Phvul.004G016500 for ANT disease and Phvul.004G036300 and Phvul.006G051500 for CBB disease. However, all the above expression data provide valuable information for further studies of ANT/CBB.

Extensive discovery and identification of disease resistance genes are the basis of resistance breeding, and SSR markers are widely used to map the disease resistance genes in the common bean. Molecular markers linked with QTLs/genes for important traits have been routinely developed for several crops, such as rice and wheat (Virk et al., 1996; Maccaferri et al., 2005; Breseghello and Sorrells, 2006). In the present 
study, we developed a series of SSR markers based on the sequence near the NBS genes. These NBS-SSR markers are closely linked to the NBS genes and display almost no recombination; thus, they can be used as co-segregation markers. These NBSSSR markers offer a powerful tool for the identification of resistant genotypes. In this study, we identified ANT and CBB resistance genes using these NBS-SSR markers. Nine NBS-SSR markers showed significant associations with ANT resistance and seven with $\mathrm{CBB}$ resistance (Table 2). Among these loci, three markers (NSSR24, NSSR73, and NSSR265) associated with ANT resistance and two markers (NSSR65 and NSSR260) associated with $\mathrm{CBB}$ resistance may be new locations by comparing to previous studies (Liu et al., 2008; Shi et al., 2011; Ferreira et al., 2013; Gonzalez et al., 2015; Perseguini et al., 2016; Zuiderveen et al., 2016). In this study, NSSR24, NSSR65, NSSR73, NSSR260 and NSSR265 were examined in a new nature population; it was confirmed that NSSR24, NSSR73, and NSSR265 also associated with ANT resistance, and NSSR260 associated with $\mathrm{CBB}$ resistance in the new population. Furthermore, we obtained the expression data of the genes only in NSSR24, NSSR65, NSSR260, and NSSR265 locations because no suitable primers were designed for the genes in NSSR73. The gene expression in NSSR24 and NSSR65 was not changed between resistant and susceptible lines or before/after inoculation. In contrast, Phvul.010G054400, one of four genes in the NSSR265 location, was expressed higher in the resistance genotype than in the susceptible genotype before inoculation. However, the gene expression for ANT declined sharply early after infection in the resistance genotype, whereas there was no change in the susceptible genotype at the cut-off level of 5.0 compared to the control. Therefore, it is possible that Phvul.010G054400 may act as a negative regulator of ANT resistance at the locus in Hongyundou during fungal infection. In addition, the sequence of the NBS gene Phvul.010G054400 was highly similar with the Arabidopsis RPP5 gene (AT4G16950). The $R P P 5$ gene belongs to TIR-NBS-LRR class, which confers higher resistance to soybean rust or other plant diseases (Eckardt, 2007; Lemos et al., 2011). According to NSSR260 for CBB, Phvul.010G025200, one of the two genes in the location, was homologous to the Arabidopsis gene AT5G36930, which encodes a TIR-NBS-LRR disease resistance protein (Tabata et al., 2000). The expression level of Phvul.010G025200 in the resistant genotype for $\mathrm{CBB}$ was higher than in the susceptible genotype after pathogen infection, suggesting that the NBS-LRR gene may increase its expression upon pathogen attack. Therefore, these results together with the genomewide association study for ANT and $\mathrm{CBB}$ provide a useful resource for NBS gene functional characterization and genetic improvement of the common bean, and perhaps for other food legumes.

In the present study, the basic information of NBS-LRR members were evaluated in the common bean. We also performed expression pattern in the different common bean organs and in response to ANT and CBB. It is important that we obtained and validated three and one new NBS loci associated with ANT and $\mathrm{CBB}$, respectively. All these results will accumulate our knowledge about NBS genes in common bean, and provide important data to expound how the PvNBS genes to respond under the disease stress.

\section{AUTHOR CONTRIBUTIONS}

JW and SW conceived and designed the experiments. JW, JZ, and LW performed the experiments. JW and JZ analyzed the data. JW, JZ, and SW contributed to the writing of the manuscript. All authors read and approved the final manuscript.

\section{FUNDING}

This work was supported by grants from the National Natural Science Foundation of China (grant No. 31671756), the Ministry of Agriculture of China [the earmarked fund for the China Agriculture Research System (CARS-09)], the National Key Technology Research and Development Program of the Ministry of Science and Technology of China (2013BAD01B03-18a), and the Agricultural Science and Technology Innovation Program (ASTIP) of CAAS.

\section{SUPPLEMENTARY MATERIAL}

The Supplementary Material for this article can be found online at: http://journal.frontiersin.org/article/10.3389/fpls.2017. 01398/full\#supplementary-material

Figure S1 | Phylogenetic tree of NBS genes from the common bean. The tree was constructed in MEGA4.0 using the neighbor-joining method with 1,000 bootstrap replicates. Red dots represent the TNL type. Each protein is encoded as follows: ID number + Domains present (TNL, TN, NTIR, NLTIR, CNL, CN, NCC, NLCC).

Figure S2 | Heat map of the expression profiles of the NBS-LRR genes across different tissues. The expression data were downloaded from the Phytozome web site. The color scale shown below the heat map represents the expression values (FPKM), with green indicating low levels, and red indicating high levels of transcript abundance.

Figure S3 | Number of differentially expressed genes for ANT and CBB. The numbers of differentially expressed genes that were exclusively up- or down-regulated for one disease are shown in each circle. The numbers of genes with common or opposite tendency of expression changes between different diseases are shown in the overlapping regions. The total numbers of up- or down-regulated genes for each disease are shown outside of the circles.

Figure S4 | Estimated population structure of 183 common bean accessions ( $K$ $=2$ ). Each group (subpopulation) is represented by a different color.

Table S1 I The phenotypic data of 183 common bean germplasms for ANT and CBB.

Table S2 | The phenotypic data of 100 common bean germplasms for ANT and CBB.

Table S3 | The primer sequences of NBS genes for QRT-PCR.

Table S4 | List of the 325 NBS proteins in the common bean.

Table S5 | List of the 178 putative NBS family genes identified in the common bean.

Table S6 | List of the $110 \mathrm{R}$ genes without the NBS domain in the common bean. Table S7 | Positions of the anchored NBS-LRR genes and cluster assignments.

Table S8 | Predicted promoter elements of common bean NBS genes.

Table S9 | Expression data of NBS genes in the common bean (the source of the data was the phytozome). 
Table S10 | The relative expression data of NBS genes in resistant and susceptible lines for ANT and CBB at four different time points.

Table S11 | SSR loci and markers for singletons.

\section{REFERENCES}

Afanador, L., Haley, S., and Kelly, J. (1993). Adoption of a "mini prep" DNA extraction method for RAPD marker analysis in common bean (Phaseolus vulgaris L.). Annu. Rep. Bean Improv. Coop. 36, 10-11.

Anderson, P. A., Lawrence, G. J., Morrish, B. C., Ayliffe, M. A., Finnegan, E. J., and Ellis, J. G. (1997). Inactivation of the flax rust resistance gene $M$ associated with loss of a repeated unit within the leucine-rich repeat coding region. Plant Cell 9, 641-651. doi: 10.1105/tpc.9.4.641

Andolfo, G., Sanseverino, W., Aversano, R., Frusciante, L., and Ercolano, M. R. (2014). Genome-wide identification and analysis of candidate genes for disease resistance in tomato. Mol. Breed. 33, 227-233. doi: 10.1007/s11032-0139928-7

Arya, P., Kumar, G., Acharya, V., and Singh, A. K. (2014). Genome-wide identification and expression analysis of NBS-encoding genes in Malus $\mathrm{x}$ domestica and expansion of NBS genes family in Rosaceae. PLoS ONE 9:e107987. doi: 10.1371/journal.pone.0107987

Bailey, T. L., Boden, M., Buske, F. A., Frith, M., Grant, C. E., Clementi, L., et al. (2009). MEME SUITE: tools for motif discovery and searching. Nucleic Acids Res. 37, W202-W208. doi: 10.1093/nar/gkp335

Balardin, R., Pastor-Corrales, M., and Otoya, M. (1990). Variabilidade patogênica de Colletotrichum lindemuthianum no estado de Santa Catarina. Fitopatol. Bras. 15, 243-245.

Bassanezi, R. B., Amorim, L., Filho, A. B., and Berger, R. D. (2002). Gas exchange and emission of chlorophyll fluorescence during the monocycle of rust, angular leaf spot and anthracnose on bean leaves as a function of their trophic characteristics. J. Phytopathol. 150, 37-47. doi: 10.1046/j.1439-0434.2002.00714.x

Bent, A. F. (1996). Plant disease resistance genes: function meets structure. Plant Cell 8, 1757-1771. doi: 10.1105/tpc.8.10.1757

Blair, M., Wu, X., Bhandari, D., Zhang, X., and Hao, J. (2016). "Role of legumes for and as horticultural crops in sustainable agriculture," in Organic Farming for Sustainable, ed D. Nandwani (Switzerland: Springer International Publishing), 185-211.

Borges, A., Tsai, S. M., and Caldas, D. G. (2012). Validation of reference genes for RT-qPCR normalization in common bean during biotic and abiotic stresses. Plant Cell Rep. 31, 827-838. doi: 10.1007/s00299-0111204-x

Bouktila, D., Khalfallah, Y., Habachi-Houimli, Y., Mezghani-Khemakhem, M., Makni, M., and Makni, H. (2014). Large-scale analysis of NBS domainencoding resistance gene analogs in Triticeae. Genet. Mol. Biol. 37, 598-610. doi: 10.1590/S1415-47572014000400017

Bouktila, D., Khalfallah, Y., Habachi-Houimli, Y., Mezghani-Khemakhem, M., Makni, M., and Makni, H. (2015). Full-genome identification and characterization of NBS-encoding disease resistance genes in wheat. Mol. Genet. Genomics 290, 257-271. doi: 10.1007/s00438-014-0909-2

Bradbury, P. J., Zhang, Z., Kroon, D. E., Casstevens, T. M., Ramdoss, Y., and Buckler, E. S. (2007). TASSEL: software for association mapping of complex traits in diverse samples. Bioinformatics 23, 2633-2635. doi: 10.1093/bioinformatics/btm308

Breseghello, F., and Sorrells, M. E. (2006). Association mapping of kernel size and milling quality in wheat (Triticum aestivum L.) cultivars. Genetics 172, 1165-1177. doi: 10.1534/genetics.105.044586

Bryan, G. T., Wu, K. S., Farrall, L., Jia, Y., Hershey, H. P., McAdams, S. A., et al. (2000). A single amino acid difference distinguishes resistant and susceptible alleles of the rice blast resistance gene Pi-ta. Plant Cell 12, 2033-2046. doi: 10.1105/tpc.12.11.2033

Campa, A., Rodríguez-Suarez, C., Giráldez, R., and Ferreira, J. J. (2014). Genetic analysis of the response to eleven Colletotrichum lindemuthianum races in a RIL population of common bean (Phaseolus vulgaris L.). BMC Plant Biol. 14:115. doi: 10.1186/1471-2229-14-115
Table S12 | SSR loci and markers for clusters.

Table S13 | Validation of SSR markers linked to new loci for ANT and CBB in 100 common bean germplasms $(p<0.01)$.

Cannon, S. B., May, G. D., and Jackson, S. A. (2009). Three sequenced legume genomes and many crop species: rich opportunities for translational genomics. Plant Physiol. 151, 970-977. doi: 10.1104/pp.109.144659

Chen, M., Wu, J., Wang, L., Mantri, N., Zhang, X., Zhu, Z., et al. (2017). Mapping and genetic structure analysis of the anthracnose resistance locus co-1hy in the common bean (Phaseolus vulgaris L.). PLoS ONE 12:e169954. doi: 10.1371/journal.pone.0169954

Chen, M., Wu, J., Wang, L., Zhang, X., Blair, M., Jia, J., et al. (2014). Development of mapped simple sequence repeat markers from common bean (Phaseolus vulgaris L.) based on genome sequences of a Chinese landrace and diversity evaluation. Mol. Breed. 33, 489-496. doi: 10.1007/s11032-013-9949-2

Cheng, Y., Li, X., Jiang, H., Ma, W., Miao, W., Yamada, T., et al. (2012). Systematic analysis and comparison of nucleotide-binding site disease resistance genes in maize. FEBS J. 279, 2431-2443. doi: 10.1111/j.1742-4658.2012.08621.x

Creusot, F., Macadré, C., Cana, E. F., Riou, C., Geffroy, V., Sévignac, M., et al. (1999). Cloning and molecular characterization of three members of the NBSLRR subfamily located in the vicinity of the Co-2 locus for anthracnose resistance in Phaseolus vulgaris. Genome 42, 254-264. doi: 10.1139/g98-134

da Maia, L. C., Palmieri, D. A., de Souza, V. Q., Kopp, M. M., de Carvalho, F. I. F., and de Oliveira, A. C. C. (2008). SSR locator: tool for simple sequence repeat discovery integrated with primer design and PCR simulation. Int. J. Plant Genomics 2008:412696. doi: 10.1155/2008/412696

David, P., Chen, N. W., Pedrosa-Harand, A., Thareau, V., Sevignac, M., Cannon, S. B., et al. (2009). A nomadic subtelomeric disease resistance gene cluster in common bean. Plant Physiol. 151, 1048-1065. doi: 10.1104/pp.109.142109

de Jesus, W. C., do Vale, F. X., Coelho, R. R., Hau, B., Zambolim, L., Costa, L. C., et al. (2001). Effects of angular leaf spot and rust on yield loss of Phaseolus vulgaris. Phytopathology 91, 1045-1053. doi: 10.1094/PHYTO.2001.91.11.1045

Deslandes, L., Olivier, J., Theulieres, F., Hirsch, J., Feng, D. X., BittnerEddy, P., et al. (2002). Resistance to Ralstonia solanacearum in Arabidopsis thaliana is conferred by the recessive RRS1-R gene, a member of a novel family of resistance genes. Proc. Natl. Acad. Sci. U.S.A. 99, 2404-2409. doi: $10.1073 /$ pnas.032485099

Eckardt, N. A. (2007). Positive and negative feedback coordinate regulation of disease resistance gene expression. Plant Cell 19, 2700-2702. doi: 10.1105/tpc.107.056226

Faktor, O., Loake, G., Dixon, R. A., and Lamb, C. J. (1997). The G-box and H-box in a 39 bp region of a French bean chalcone synthase promoter constitute a tissue-specific regulatory element. Plant. J. 11, 1105-1113. doi: 10.1046/j.1365-313X.1997.11051105.x

Ferreira, J., Campa, A., and Kelly, J. (2013). "Organization of genes conferring resistance to anthracnose in common bean," in Translational Genomic for Crop Breeding, vol. I, Biotic Stresses, eds R. K. Varshney and R. Tuberosa (New York, NY: Wiley), 151-181.

Ferrier-Cana, E., Macadre, C., Sevignac, M., David, P., Langin, T., and Geffroy, V. (2005). Distinct post-transcriptional modifications result into seven alternative transcripts of the CC-NBS-LRR gene JA1tr of Phaseolus vulgaris. Theor. Appl. Genet. 110, 895-905. doi: 10.1007/s00122-004-1908-1

Finn, R. D., Clements, J., Arndt, W., Miller, B. L., Wheeler, T. J., Schreiber, F., et al. (2015). HMMER web server: 2015 update. Nucleic Acids Res. 43, W30-W38. doi: 10.1093/nar/gkv397

Fourie, D. (2002). Distribution and severity of bacterial diseases on dry beans (Phaseolus vulgaris L.) in South Africa. J. Phytopathol. 150, 220-226. doi: 10.1046/j.1439-0434.2002.00745.x

Friedman, A. R., and Baker, B. J. (2007). The evolution of resistance genes in multi-protein plant resistance systems. Curr. Opin. Genet. Dev. 17, 493-499. doi: 10.1016/j.gde.2007.08.014

Gao, L., Turner, M. K., Chao, S., Kolmer, J., and Anderson, J. A. (2016). Genome wide association study of seedling and adult plant leaf rust resistance in elite spring wheat breeding lines. PLoS ONE 11:e0148671. doi: 10.1371/journal.pone.0148671 
Garzon, L. N., Oliveros, O. A., Rosen, B., Ligarreto, G. A., Cook, D. R., and Blair, M. W. (2013). Isolation and characterization of nucleotide-binding site resistance gene homologues in common bean (Phaseolus vulgaris). Phytopathology 103, 156-168. doi: 10.1094/PHYTO-07-12-0180-R

Gepts, P., Beavis, W. D., Brummer, E. C., Shoemaker, R. C., Stalker, H. T., Weeden, N. F., et al. (2005). Legumes as a model plant family. Genomics for food and feed report of the cross-legume advances through genomics conference. Plant Physiol. 137, 1228-1235. doi: 10.1104/pp.105.060871

Gonzalez, A. M., Yuste-Lisbona, F. J., Rodiño, A. P., De Ron, A. M., Capel, C., Garcia-Alcazar, M., et al. (2015). Uncovering the genetic architecture of Colletotrichum lindemuthianum resistance through QTL mapping and epistatic interaction analysis in common bean. Front. Plant Sci. 6:141. doi: 10.3389/fpls.2015.00141

Gu, L., Si, W., Zhao, L., Yang, S., and Zhang, X. (2015). Dynamic evolution of NBS-LRR genes in bread wheat and its progenitors. Mol. Genet. Genomics 290, 727-738. doi: 10.1007/s00438-014-0948-8

Guo, A. Y., Zhu, Q. H., Chen, X., and Luo, J. C. (2007). GSDS: a gene structure display server. Yi Chuan 29, 1023-1026. doi: 10.1360/yc-007-1023

Gurung, S., Mamidi, S., Bonman, J. M., Xiong, M., Brown-Guedira, G., and Adhikari, T. B. (2014). Genome-wide association study reveals novel quantitative trait loci associated with resistance to multiple leaf spot diseases of spring wheat. PLoS ONE 9:e108179. doi: 10.1371/journal.pone.0108179

Hayashi, N., Inoue, H., Kato, T., Funao, T., Shirota, M., Shimizu, T., et al. (2010). Durable panicle blast-resistance gene $P b 1$ encodes an atypical CC-NBS-LRR protein and was generated by acquiring a promoter through local genome duplication. Plant J. 64, 498-510. doi: 10.1111/j.1365-313X.2010.04348.x

Hayashi, S., Reid, D. E., Lorenc, M. T., Stiller, J., Edwards, D., Gresshoff, P. M., et al. (2012). Transient Nod factor-dependent gene expression in the nodulationcompetent zone of soybean (Glycine max [L.] Merr.) roots. Plant Biotechnol. J. 10, 995-1010. doi: 10.1111/j.1467-7652.2012.00729.x

Iquira, E., Humira, S., and François, B. (2015). Association mapping of QTLs for sclerotinia stem rot resistance in a collection of soybean plant introductions using a genotyping by sequencing (GBS) approach. BMC Plant Biol. 15:5. doi: 10.1186/s12870-014-0408-y

Iyer, A. S., and McCouch, S. R. (2004). The rice bacterial blight resistance gene xa5 encodes a novel form of disease resistance. Mol. Plant Microbe Interact. 17, 1348-1354. doi: 10.1094/MPMI.2004.17.12.1348

Jain, M., Misra, G., Patel, R. K., Priya, P., Jhanwar, S., Khan, A. W., et al. (2013). A draft genome sequence of the pulse crop chickpea (Cicer arietinum L.). Plant J. 74, 715-729. doi: $10.1111 /$ tpj.12173

Jansman, A. (2005). Grain legumes as functional ingredients in animal feeds. Grain Legumes 41:12.

Kang, Y. J., Kim, K. H., Shim, S., Yoon, M. Y., Sun, S., Kim, M. Y., et al. (2012). Genome-wide mapping of NBS-LRR genes and their association with disease resistance in soybean. BMC Plant Biol. 12:139. doi: 10.1186/1471-2229-12-139

Kang, Y. J., Kim, S. K., Kim, M. Y., Lestari, P., Kim, K. H., Ha, B. K., et al. (2014). Genome sequence of mungbean and insights into evolution within Vigna species. Nat. Commun. 5:5443. doi: 10.1038/ncomms6443

Kim, Y. W., Jung, H. J., Park, J. I., Hur, Y., and Nou, I. S. (2015). Response of NBS encoding resistance genes linked to both heat and fungal stress in Brassica oleracea. Plant Physiol. Biochem. 86, 130-136. doi: 10.1016/j.plaphy.2014.11.009

Kohler, A., Rinaldi, C., Duplessis, S., Baucher, M., Geelen, D., Duchaussoy, F., et al. (2008). Genome-wide identification of NBS resistance genes in Populus trichocarpa. Plant Mol. Biol. 66, 619-636. doi: 10.1007/s11103-008-9293-9

Lakshmanan, V., Castaneda, R., Rudrappa, T., and Bais, H. P. (2013). Root transcriptome analysis of Arabidopsis thaliana exposed to beneficial Bacillus subtilis FB17 rhizobacteria revealed genes for bacterial recruitment and plant defense independent of malate efflux. Planta 238, 657-668. doi: 10.1007/s00425-013-1920-2

Larkin, M. A., Blackshields, G., Brown, N. P., Chenna, R., McGettigan, P. A., McWilliam, H., et al. (2007). Clustal, W., and Clustal X version 2.0. Bioinformatics 23, 2947-2948. doi: 10.1093/bioinformatics/btm404

Lawrence, G. J., Finnegan, E. J., Ayliffe, M. A., and Ellis, J. G. (1995). The L6 gene for flax rust resistance is related to the Arabidopsis bacterial resistance gene RPS2 and the tobacco viral resistance gene N. Plant Cell 7, 1195-1206. doi: 10.1105/tpc.7.8.1195

Lemos, N. G., de Lucca e Braccini, A., Abdelnoor, R. V., de Oliveira, M. C. N., Suenaga, K., and Yamanaka, N. (2011). Characterization of genes
Rpp2, Rpp4, and Rpp5 for resistance to soybean rust. Euphytica 182, 53-64 doi: 10.1007/s10681-011-0465-3

Ling, H. Q., Zhao, S., Liu, D., Wang, J., Sun, H., Zhang, C., et al. (2013). Draft genome of the wheat A-genome progenitor Triticum urartu. Nature 496, 87-90. doi: 10.1038/nature11997

Liu, S., Yu, K., and Park, S. J. (2008). Development of STS markers and QTL validation for common bacterial blight resistance in common bean. Plant Breed. 127, 62-68. doi: 10.1111/j.1439-0523.2007.01423.x

Liu, W., Frick, M., Huel, R., Nykiforuk, C. L., Wang, X., Gaudet, D. A., et al. (2014). The stripe rust resistance gene Yr10 encodes an evolutionary-conserved and unique CC-NBS-LRR sequence in wheat. Mol. Plant 7, 1740-1755. doi: $10.1093 / \mathrm{mp} / \mathrm{ssu} 112$

Livak, K. J., and Schmittgen, T. D. (2001). Analysis of relative gene expression data using real-time quantitative PCR and the $2^{-\Delta \Delta C T}$ method. Methods 25, 402-408. doi: 10.1006/meth.2001.1262

Lozano, R., Hamblin, M. T., Prochnik, S., and Jannink, J. L. (2015). Identification and distribution of the NBS-LRR gene family in the Cassava genome. BMC Genomics 16:360. doi: 10.1186/s12864-015-1554-9

Lozano, R., Ponce, O., Ramirez, M., Mostajo, N., and Orjeda, G. (2012). Genome-wide identification and mapping of NBS-encoding resistance genes in Solanum tuberosum group phureja. PLoS ONE 7:e34775. doi: 10.1371/journal.pone.0034775

Lurin, C., Andres, C., Aubourg, S., Bellaoui, M., Bitton, F., Bruyere, C., et al. (2004). Genome-wide analysis of Arabidopsis pentatricopeptide repeat proteins reveals their essential role in organelle biogenesis. Plant Cell 16, 2089-2103. doi: $10.1105 /$ tpc. 104.022236

Ma, J., Lei, C., Xu, X., Hao, K., Wang, J., Cheng, Z., et al. (2015). Pi64, encoding a novel CC-NBS-LRR protein, confers resistance to leaf and neck blast in rice. Mol. Plant Microbe Interact. 28, 558-568. doi: 10.1094/MPMI-11-14-0367-R

Maccaferri, M., Sanguineti, M. C., Noli, E., and Tuberosa, R. (2005). Population structure and long-range linkage disequilibrium in a durum wheat elite collection. Mol. Breed. 15, 271-290. doi: 10.1007/s11032-004-7012-z

Mace, E., Tai, S., Innes, D., Godwin, I., Hu, W., Campbell, B., et al. (2014). The plasticity of NBS resistance genes in Sorghum is driven by multiple evolutionary processes. BMC Plant Biol. 14:253. doi: 10.1186/s12870-014-0253-z

Martin, G. B., Bogdanove, A. J., and Sessa, G. (2003). Understanding the functions of plant disease resistance proteins. Annu. Rev. Plant Biol. 54, 23-61. doi: 10.1146/annurev.arplant.54.031902.135035

McConnell, M., Mamidi, S., Lee, R., Chikara, S., Rossi, M., Papa, R., et al. (2010). Syntenic relationships among legumes revealed using a gene-based genetic linkage map of common bean (Phaseolus vulgaris L.). Theor. Appl. Genet. 121, 1103-1116. doi: 10.1007/s00122-010-1375-9

McHale, L., Tan, X., Koehl, P., and Michelmore, R. W. (2006). Plant NBS-LRR proteins: adaptable guards. Genome Biol. 7:212. doi: 10.1186/gb-2006-7-4-212

Melotto, M., Balardin, R., and Kelly, J. (2000). "Host-pathogen interaction and variability of Colletotrichum lindemuthianum," in Colletotrichum Host Specificity, Pathology, and Host-Pathogen Interaction, eds D. Prusky, S. Freeman, and M. Dickman (St. Paul, MN: APS Press), 346-361.

Meyers, B. C., Kozik, A., Griego, A., Kuang, H., and Michelmore, R. W. (2003). Genome-wide analysis of NBS-LRR-encoding genes in Arabidopsis. Plant Cell 15, 809-834. doi: 10.1105/tpc.009308

Miklas, P. N., Coyne, D. P., Grafton, K. F., Mutlu, N., Reiser, J., Lindgren, D. T. et al. (2003). A major QTL for common bacterial blight resistance derives from the common bean great northern landrace cultivar Montana No.5. Euphytica 131, 137-146. doi: 10.1023/A:1023064814531

Miklas, P. N., Kelly, J. D., Beebe, S. E., and Blair, M. W. (2006). Common bean breeding for resistance against biotic and abiotic stresses: from classical to MAS breeding. Euphytica 147, 105-131. doi: 10.1007/s10681-0064600-5

Mun, J. H., Yu, H. J., Park, S., and Park, B. S. (2009). Genome-wide identification of NBS-encoding resistance genes in Brassica rapa. Mol. Genet. Genomics 282, 617-631. doi: 10.1007/s00438-009-0492-0

Noel, L., Moores, T. L., van Der Biezen, E. A., Parniske, M., Daniels, M. J., Parker, J. E., et al. (1999). Pronounced intraspecific haplotype divergence at the RPP5 complex disease resistance locus of Arabidopsis. Plant Cell 11, 2099-2112. doi: 10.1105/tpc.11.11.2099

Olukolu, B. A., Wang, G. F., Vontimitta, V., Venkata, B. P., Marla, S., Ji, J., et al. (2014). A genome-wide association study of the maize hypersensitive 
defense response identifies genes that cluster in related pathways. PLoS Genet. 10:e1004562. doi: 10.1371/journal.pgen.1004562

Opio, A. F., Allen, D. J., and Teri, J. M. (1996). Pathogenic variation in Xanthomonas campestris pv. phaseoli, the causal agent of common bacterial blight in Phaseolus beans. Plant Pathol. 45, 1126-1133. doi: 10.1046/j.1365-3059.1996.d01-187.x

O’Toole, N., Hattori, M., Andres, C., Iida, K., Lurin, C., Schmitz-Linneweber, C., et al. (2008). On the expansion of the pentatricopeptide repeat gene family in plants. Mol. Biol. Evol. 25, 1120-1128. doi: 10.1093/molbev/msn057

Periyannan, S., Moore, J., Ayliffe, M., Bansal, U., Wang, X., Huang, L., et al. (2013). The gene Sr33, an ortholog of barley Mla genes, encodes resistance to wheat stem rust race Ug99. Science 341, 786-788. doi: 10.1126/science.1239028

Perseguini, J. M., Oblessuc, P. R., Rosa, J. R., Gomes, K. A., Chiorato, A. F., Carbonell, S. A., et al. (2016). Genome-wide association studies of anthracnose and angular leaf spot resistance in common bean (Phaseolus vulgaris L.). PLoS ONE 11:e0150506. doi: 10.1371/journal.pone.0150506

Pritchard, J. K., Stephens, M., and Donnelly, P. (2000). Inference of population structure using multilocus genotype data. Genetics 155, 945-959.

Rombauts, S., Dehais, P., Van Montagu, M., and Rouze, P. (1999). PlantCARE, a plant cis-acting regulatory element database. Nucleic Acids Res. 27, 295-296. doi: 10.1093/nar/27.1.295

Rushton, P. J., Torres, J. T., Parniske, M., Wernert, P., Hahlbrock, K., and Somssich, I. E. (1996). Interaction of elicitor-induced DNA-binding proteins with elicitor response elements in the promoters of parsley PR1 genes. EMBO J. 15, 5690-5700.

Saintenac, C., Zhang, W., Salcedo, A., Rouse, M. N., Trick, H. N., Akhunov, E., et al. (2013). Identification of wheat gene Sr35 that confers resistance to Ug99 stem rust race group. Science 341, 783-786. doi: 10.1126/science.1239022

Schmutz, J., McClean, P. E., Mamidi, S., Wu, G. A., Cannon, S. B., Grimwood, J., et al. (2014). A reference genome for common bean and genome-wide analysis of dual domestications. Nat. Genet. 46, 707-713. doi: 10.1038/ng.3008

Schwartz, H., Correa, V., Pineda, D., Otoya, M. M. M., and Katherman, M. (1981). Dry bean yield losses caused by Ascochyta, angular, and white leaf spots in Colombia. Plant Dis. 65, 1494-1496. doi: 10.1094/PD-65-494

Sekhwal, M. K., Li, P., Lam, I., Wang, X., Cloutier, S., and You, F. M. (2015). Disease resistance gene analogs (RGAs) in plants. Int. J. Mol. Sci. 16, 19248-19290. doi: 10.3390/ijms160819248

Seo, Y. S., Rojas, M. R., Lee, J. Y., Lee, S. W., Jeon, J. S., Ronald, P., et al. (2006). A viral resistance gene from common bean functions across plant families and is up-regulated in a non-virus-specific manner. Proc. Natl. Acad. Sci. U.S.A. 103, 11856-11861. doi: 10.1073/pnas.0604815103

Shi, C., Navabi, A., and Yu, K. (2011). Association mapping of common bacterial blight resistance QTL in Ontario bean breeding populations. BMC Plant Biol. 11:52. doi: 10.1186/1471-2229-11-52

Shi, L., Weng, J., Liu, C., Song, X., Miao, H., Hao, Z., et al. (2013). Identification of promoter motifs regulating ZmeIF4E expression level involved in maize rough dwarf disease resistance in maize (Zea mays L.). Mol. Genet. Genomics 288, 89-99. doi: 10.1007/s00438-013-0737-9

Shiu, S. H., Karlowski, W. M., Pan, R., Tzeng, Y. H., Mayer, K. F., and Li, W. H. (2004). Comparative analysis of the receptor-like kinase family in Arabidopsis and rice. Plant Cell 16, 1220-1234. doi: 10.1105/tpc.020834

Singh, S., Chand, S., Singh, N. K., and Sharma, T. R. (2015). Genome-wide distribution, organisation and functional characterization of disease resistance and defence response genes across rice species. PLOS ONE 10:e0125964. doi: 10.1371/journal.pone. 0125964

Singh, S. P., and Schwartz, H. F. (2010). Breeding common bean for resistance to diseases: a review. Crop Sci. 50, 2199-2223. doi: 10.2135/cropsci2009.03.0163

Song, H., and Nan, Z. (2014). Genome-wide analysis of nucleotide-binding site disease resistance genes in Medicago truncatula. Chin. Sci. Bull. 59, 1129-1138. doi: 10.1007/s11434-014-0155-3

Song, H., Wang, P., Li, C., Han, S., Zhao, C., Xia, H., et al. (2017). Comparative analysis of NBS-LRR genes and their response to Aspergillus flavus in Arachis. PLoS ONE 12:e0171181. doi: 10.1371/journal.pone.0171181

Tabata, S., Kaneko, T., Nakamura, Y., Kotani, H., Kato, T., Asamizu, E., et al. (2000). Sequence and analysis of chromosome 5 of the plant Arabidopsis thaliana. Nature 408, 823-826. doi: 10.1038/35048507

Tameling, W. I., Vossen, J. H., Albrecht, M., Lengauer, T., Berden, J. A., Haring, M. A., et al. (2006). Mutations in the NB-ARC domain of I-2 that impair ATP hydrolysis cause autoactivation. Plant Physiol. 140, 1233-1245. doi: 10.1104/pp.105.073510

Tamura, K., Dudley, J., Nei, M., and Kumar, S. (2007). MEGA4: molecular evolutionary genetics analysis (MEGA) software version 4.0 Mol. Biol. Evol. 24, 1596-1599. doi: 10.1093/molbev/msm092

Tan, S., and Wu, S. (2012). Genome wide analysis of nucleotide-binding site disease resistance genes in Brachypodium distachyon. Comp. Funct. Genomics 2012, 1-12. doi: 10.1155/2012/418208

Trabanco, N., Pérez-Vega, E., Campa, A., Rubiales, D., and Ferreira, J. J. (2012). Genetic resistance to powdery mildew in common bean. Euphytica 186, 875-882. doi: 10.1007/s10681-012-0663-7

Vallejos, C. E., Astua-Monge, G., Jones, V., Plyler, T. R., Sakiyama, N. S., and Mackenzie, S. A. (2006). Genetic and molecular characterization of the I locus of Phaseolus vulgaris. Genetics 172, 1229-1242. doi: 10.1534 /genetics.105.050815

Varshney, R. K., Chen, W., Li, Y., Bharti, A. K., Saxena, R. K., Schlueter, J. A., et al. (2012). Draft genome sequence of pigeonpea (Cajanus cajan), an orphan legume crop of resource-poor farmers. Nat. Biotechnol. 30, 83-89. doi: $10.1038 /$ nbt.2022

Varshney, R. K., Song, C., Saxena, R. K., Azam, S., Yu, S., Sharpe, A. G., et al. (2013). Draft genome sequence of chickpea (Cicer arietinum) provides a resource for trait improvement. Nat. Biotechnol. 31, 240-246. doi: 10.1038/nbt.2491

Virk, P. S., Ford-Lloyd, B. V., Jackson, M. T., Pooni, H. S., Clemeno, T. P., and Newbury, H. J. (1996). Predicting quantitative variation within rice germplasm using molecular markers. Heredity 76, 296-304. doi: 10.1038/hdy.1996.43

Vlasova, A., Capella-Gutierrez, S., Rendon-Anaya, M., Hernandez-Onate, M., Minoche, A. E., Erb, I., et al. (2016). Genome and transcriptome analysis of the Mesoamerican common bean and the role of gene duplications in establishing tissue and temporal specialization of genes. Genome Biol. 17:32. doi: 10.1186/s13059-016-0883-6

Wang, S. S., Wang, F., Tan, S. J., Wang, M. X., Sui, N., and Zhang, X. S. (2014). Transcript profiles of maize embryo sacs and preliminary identification of genes involved in the embryo sac-pollen tube interaction. Front. Plant Sci. 5:702. doi: $10.3389 /$ fpls.2014.00702

Warren, R. F., Henk, A., Mowery, P., Holub, E., and Innes, R. W. (1998). A mutation within the leucine-rich repeat domain of the Arabidopsis disease resistance gene RPS5 partially suppresses multiple bacterial and downy mildew resistance genes. Plant Cell 10, 1439-1452. doi: 10.1105/tpc.10.9.1439

Whitham, S., Dinesh-Kumar, S. P., Choi, D., Hehl, R., Corr, C., and Baker, B. (1994). The product of the tobacco mosaic virus resistance gene $\mathrm{N}$ : similarity to toll and the interleukin-1 receptor. Cell 78, 1101-1115. doi: 10.1016/0092-8674(94)90283-6

Xie, W., Khanal, R., McClymont, S., Stonehouse, R., Bett, K., Yu, K., et al. (2017). Interaction of quantitative trait loci for resistance to common bacterial blight and pathogen isolates in Phaseolus vulgaris L. Mol. Breed. 37:55. doi: 10.1007/s11032-017-0657-1

Yamamoto, S., Nakano, T., Suzuki, K., and Shinshi, H. (2004). Elicitor-induced activation of transcription via $\mathrm{W}$ box-related cis-acting elements from a basic chitinase gene by WRKY transcription factors in tobacco. Biochim. Biophys. Acta 1679, 279-287. doi: 10.1016/j.bbaexp.2004.07.005

Yang, K., Tian, Z., Chen, C., Luo, L., Zhao, B., Wang, Z., et al. (2015). Genome sequencing of adzuki bean (Vigna angularis) provides insight into high starch and low fat accumulation and domestication. Proc. Natl. Acad. Sci. U.S.A. 112, 13213-13218. doi: 10.1073/pnas.1420949112

Yang, S., Zhang, X., Yue, J. X., Tian, D., and Chen, J. Q. (2008). Recent duplications dominate NBS-encoding gene expansion in two woody species. Mol. Genet. Genomics 280, 187-198. doi: 10.1007/s00438-008-0355-0

Yoshimura, S., Yamanouchi, U., Katayose, Y., Toki, S., Wang, Z. X., Kono, I., et al. (1998). Expression of Xal, a bacterial blight-resistance gene in rice, is induced by bacterial inoculation. Proc. Natl. Acad. Sci. U.S.A. 95, 1663-1668. doi: $10.1073 /$ pnas.95.4.1663

Yu, J., Tehrim, S., Zhang, F., Tong, C., Huang, J., Cheng, X., et al. (2014). Genomewide comparative analysis of NBS-encoding genes between Brassica species and Arabidopsis thaliana. BMC Genomics 15:3. doi: 10.1186/1471-2164-15-3

Zamani, Z., Bahar, M., Jacques, M. A., Lak, M. R., and Akhavan, A. (2011). Genetic diversity of the common bacterial blight pathogen of bean, Xanthomonas axonopodis pv. phaseoli, in Iran revealed by rep-PCR and PCR-RFLP analyses. World J. Microbiol. Biotechnol. 27, 2371-2378. doi: 10.1007/s11274-011-0705-7 
Zapata, M. (2006). Proposed of a uniform screening procedure for the evaluation of variability of Xanthomonas axonopodis pv. phaseoli and resistance on leaves of Phaseolus vulgaris under greenhouse conditions. Ann. Rep. Bean Improv. Coop. 49, 213-214.

Zegeye, H., Rasheed, A., Makdis, F., Badebo, A., and Ogbonnaya, F. C. (2014). Genome-wide association mapping for seedling and adult plant resistance to stripe rust in synthetic hexaploid wheat. PLOS ONE 9:e105593. doi: 10.1371/journal.pone.0105593

Zhang, X., Yang, S., Wang, J., Jia, Y., Huang, J., Tan, S., et al. (2015). A genomewide survey reveals abundant rice blast $\mathrm{R}$ genes in resistant cultivars. Plant J. 84, 20-28. doi: 10.1111/tpj.12955

Zhou, F., Kurth, J., Wei, F., Elliott, C., Vale, G., Yahiaoui, N., et al. (2001). Cellautonomous expression of barley Mla1 confers race-specific resistance to the powdery mildew fungus via a Rar1-independent signaling pathway. Plant Cell 13, 337-350. doi: 10.1105/tpc.13.2.337

Zhou, T., Wang, Y., Chen, J. Q., Araki, H., Jing, Z., Jiang, K., et al. (2004). Genomewide identification of NBS genes in Japonica rice reveals significant expansion of divergent non-TIR NBS-LRR genes. Mol. Genet. Genomics 271, 402-415. doi: 10.1007/s00438-004-0990-Z

Zuiderveen, G. H., Padder, B. A., Kamfwa, K., Song, Q., and Kelly, J. D. (2016). Genome-wide association study of anthracnose resistance in Andean beans (Phaseolus vulgaris). PLoS ONE 11:e0156391. doi: 10.1371/journal.pone.0156391

Conflict of Interest Statement: The authors declare that the research was conducted in the absence of any commercial or financial relationships that could be construed as a potential conflict of interest.

Copyright (c) $2017 \mathrm{Wu}, \mathrm{Zhu}$, Wang and Wang. This is an open-access article distributed under the terms of the Creative Commons Attribution License (CC BY). The use, distribution or reproduction in other forums is permitted, provided the original author(s) or licensor are credited and that the original publication in this journal is cited, in accordance with accepted academic practice. No use, distribution or reproduction is permitted which does not comply with these terms. 